\title{
Assays for the identification and quantification of sialic acids: challenges, opportunities and future perspectives
}

Article

Accepted Version

Creative Commons: Attribution-Noncommercial-No Derivative Works 4.0

Cheeseman, J., Kuhnle, G. ORCID: https://orcid.org/00000002-8081-8931, Spencer, D. I.R. and Osborn, H. (2021) Assays for the identification and quantification of sialic acids: challenges, opportunities and future perspectives. Bioorganic \& Medicinal Chemistry, 30. 115882. ISSN 0968-0896 doi: https://doi.org/10.1016/j.bmc.2020.115882 Available at https://centaur.reading.ac.uk/93964/

It is advisable to refer to the publisher's version if you intend to cite from the work. See Guidance on citing.

To link to this article DOI: http://dx.doi.org/10.1016/j.bmc.2020.115882

Publisher: Elsevier

All outputs in CentAUR are protected by Intellectual Property Rights law, including copyright law. Copyright and IPR is retained by the creators or other copyright holders. Terms and conditions for use of this material are defined in the End User Agreement. 


\section{CentAUR}

Central Archive at the University of Reading

Reading's research outputs online 


\title{
Assays for the identification and quantification of sialic acids: challenges, opportunities and future perspectives
}

\author{
Jack Cheeseman ${ }^{a}$, Gunter Kuhnle ${ }^{\mathrm{b}}$, Daniel I.R. Spencer ${ }^{\mathrm{c}}$, Helen M.I. Osborn*a \\ a School of Pharmacy, University of Reading, Whiteknights, Reading, UK. RG6 6AD \\ b Department of Food and Nutritional Sciences, University of Reading, Whiteknights, \\ Reading, UK. RG6 6AH \\ ${ }^{c}$ Ludger Ltd, Culham Science Centre, Abingdon, UK. OX14 3EB
}

Keywords: Sialic acid, biomarker, colorimetric assays, fluorometric assays, chromatographic assays, enzymatic assays

\begin{abstract}
$\mathrm{N}$-Acetyl neuraminic acid (sialic acid) is a monosaccharide generally found as the terminating unit on glycans, which in turn are found on the surface of cells and glycoproteins. These glycans aid in a variety of biological functions such as cell interactions and immune response. Sialic acid has been identified as a biomarker for cardiovascular disease, diabetes and a range of other inflammatory and degenerative conditions. It has also been identified as a marker for different types of cancer. Sialic acid levels vary depending on the level of inflammation present during the course of an inflammatory disease and it is overexpressed by tumours as a shield against the immune system. Since the discovery of sialic acid, numerous assays have been developed for the identification and quantification of different sialic acid derivative monosaccharides and these assays fall into four main groups: colorimetric, fluorometric, enzymatic and chromatographic/mass spectrometric, with much overlap between these. Given the importance of sialic acids in biological pathways, this review article critically appraises assays that are used to detect and quantify sialic acid and its derivatives. Thus it details the method, sensitivity, specificity and wider scope of a range of assays, and concludes by suggesting some future directions for assay development and application. In this way, insight is provided into assays that allow for the accurate quantitation of sialic acid in biological samples, which may facilitate identification of the roles of sialic acid in healthy and disease pathways.
\end{abstract}




\section{Introduction}

$N$-Acetyl neuraminic acid (figure 1), also known as sialic acid, is an acetylated derivative of the acidic sugar neuraminic acid. It is one of a family of over 50 different neuraminic acids (sialic acids) ${ }^{1}$ which includes members with different functional group at the 5-position, for example an $\mathrm{N}$-acetyl group, an $\mathrm{N}$-glycol group, a hydroxyl group (KDN) or, in the case of neuraminic acid itself, an unsubstituted amine group. Further differences can be found in the position and number of hydroxyl group substituents (for example acetyl, methyl, lactyl, phosphate, sulfate). ${ }^{2}$ Additional diversity in sialic acids result due to the opportunity for different glycosidic linkages between the 2-position on sialic acid and other carbohydrate frameworks. Sialic acids are generally found as the terminating unit on glycans, but can also be found as free molecules, especially in the form of $N$-acetyl neuraminic acid. ${ }^{3}$

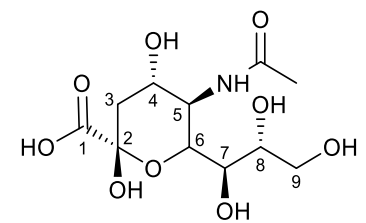

Figure 1: $N$-Acetyl neuraminic acid

Sialic acid is important for many different biological processes and for normal cell function. It exhibits a negative charge under physiological conditions which is subsequently associated with cells due to sialic acid being found at the cell surface. This negative charge aids in the aggregation of cells and positively charged species, and the repulsion of other cells. ${ }^{4}$ This is especially important for erythrocytes as this charge aids in preventing aggregation and clotting. Sialic acid is also important for recognition by receptors which will not function without the presence of sialic acid, one such example is the influenza virus which cannot propagate without sialic acid. ${ }^{5,6}$ In contrast, sialic acid also helps to block the action of other receptors, in the case of the immune system, where it can act as a biological mask to prevent attack and clearance by the immune system. ${ }^{7}$ This is utilised by both host cells and foreign bodies. Hypersialylation in cancer is especially prevalent as this assists the cancer cells in evading the immune system, proliferating and metastasising, resisting cancer therapies and subsequent cell death, and promoting angiogenesis. ${ }^{8}$

Analysis of sialic acid is critical due to its identification as a marker of various disease states. Thus sialic acid, whether naturally found as the monosaccharide or artificially released via chemical or enzymatic means, has previously been identified as a marker for general cardiovascular (CVD) risk and associated diseases such as coronary artery disease (CAD) ${ }^{9}$, 
stroke $^{10}$ and diabetes ${ }^{11}$, as well as different cancers ${ }^{12-15}$. Sialic acid is overexpressed during the pathogenesis of these diseases and, as such, sialic acid can be indicative of the presence of the disease. Identification and quantification of sialic acid could therefore help in validating sialic acid as a marker for these diseases aiding in diagnosis and more rapid treatment. For example, Table 1 illustrates how the levels of serum sialic acid vary in healthy volunteers and patients with CAD, CVD, diabetes and cancer.

\begin{tabular}{|l|l|l|l|}
\hline $\begin{array}{l}\text { N Number of } \\
\text { volunteers) }\end{array}$ & $\begin{array}{l}\text { Mean serum } \\
\text { TSA (mmol/L) }\end{array}$ & Healthy volunteer/disease state & Ref \\
\hline 138 & 2.17 & Healthy & 16 \\
\hline 60 & 2.17 & Healthy & 17 \\
\hline 24 & 2.14 & Healthy & 18 \\
\hline 20 & 1.98 & Healthy & 19 \\
\hline 20 & 1.94 & Healthy & 20 \\
\hline 92 & 2.26 & CAD & 18 \\
\hline 97 & 2.95 & CVD & 21 \\
\hline 411 & 2.63 & CAD and Type 2 diabetes & 22 \\
\hline 540 & 2.61 & Prostate cancer & 23 \\
\hline 242 & 2.46 & Colorectal cancer & 24 \\
\hline
\end{tabular}

Table 1: Levels of serum Total sialic acid (TSA) in healthy volunteers and patients with CVD, diabetes or cancer

The history of sialic acid, its biological functions, and a brief overview of the development of assays for the identification and quantification of sialic acid have previously been reviewed by Schauer et al. ${ }^{25}$ The review presented herein builds on this earlier report and broadens the perspective in order to include a wider range of approaches that are used to detect and quantify sialic acid and its derivatives, with a focus on the method, sensitivity, specificity and wider scope of the strategy. Advantages and disadvantages of both historical and modern methods are provided, allowing the reader to make an informed decision on the optimum assay that meets the needs of their particular research programme.

\section{Colorimetric methods for quantification of sialic acid}

Colorimetric methods for the analysis of sialic acid and its derivatives were some of the first methods developed for quantifying sialic acids in biological samples. These methods generally involve the release of bound sialic acids from proteins and lipids with mild acid hydrolysis. This is then followed by the formation of an intermediate compound that can be 
reacted with the main reagent to give a chromophore, wherein the absorbance can be measured to quantify any sialic acids present.

Some early methods developed for colorimetric analysis of sialic acids were not particularly successful. These utilised reagents such as diphenylamine ${ }^{26}$ and dimethylaminobenzaldehyde. ${ }^{27}$ to form chromophores. Sulfuric acid/acetic acid, ${ }^{28} \mathrm{HCl},{ }^{29}$ ethanoic acid/sulfonic acid ${ }^{30}$ were also utilised to form humin, which in turn, could be detected and used for quantitation. These suffered from poor specificity for sialic acid. Hexoses, pentoses, deoxy sugars and ketohexoses can also react under many of the assay conditions, resulting in generally inflated measurements for sialic acid content in samples, which is not favourable. They also suffered from poor sensitivity and as such were not particularly well suited for analysis of sialic acids. The methods outlined below, while still suffering from specificity and sensitivity issues, were better and more well suited to the analyses required at the time. The following methods, with the exception of the MBTH assay, could only be utilised for the analysis of total quantity of sialic acids in a sample due to their inability to distinguish between different sialic acid derivatives. In contrast, the MBTH assay was utilised to analyse the degree of 8 and 9- $O$ acetylation in the sample.

\subsection{Orcinol}

This method, developed by Klenk et al. for the analysis of sialic acid, was reported in $1941 .^{31}$ It involves the use of a mild acid to cleave sialic acid from its glyosidic bonds followed by reaction of the liberated sialic acids with Bial's reagent $(40.7 \mathrm{~mL}$ conc. $\mathrm{HCl}, 0.1 \mathrm{~g}$ orcinol, 1 $\mathrm{mL} 1 \% \mathrm{FeCl}_{3}$ and $50 \mathrm{~mL}$ water). The liberated sialic acid is boiled at $100^{\circ} \mathrm{C}$ in the Bials reagent to give reactive intermediate ketone $\mathbf{2}$ (scheme 1), which reacts with orcinol to give a chromogen 3 that can be extracted from aqueous solution using isoamyl alcohol to give a chromophore 5. This chromophore has a maximum absorbance at $572 \mathrm{~nm}$. This method is limited however as it can suffer from interference from hexoses, pentoses and uronic acids and as such does not have very good specificity and results may not be very accurate. This is because under the conditions utilised for the orcinol assay the hexoses and pentoses form furfural and hydroxymethylfurfural, while uronic acids form 2-furancarboxylic acid and 5formyl-2-furancarboxylic acid (Figure 1). ${ }^{32}$ These compounds react with orcinol in a similar way to compound $\mathbf{2}$ to form a variety of chromophores. Scheme 1 illustrates the conversion of sialic acid into the reactive intermediate ${ }^{33}$ that will react with orcinol to give the chromophore as illustrated in scheme $2 .^{25}$ 
<smiles>CC(=O)N[C@@H]1C([C@H](O)[C@H](O)CO)O[C@](O)(C(=O)O)C[C@@H]1O</smiles>

1

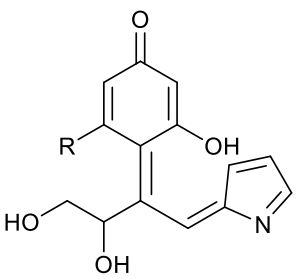

5<smiles>O=C(Cc1ccc[nH]1)C(O)CO</smiles>

2
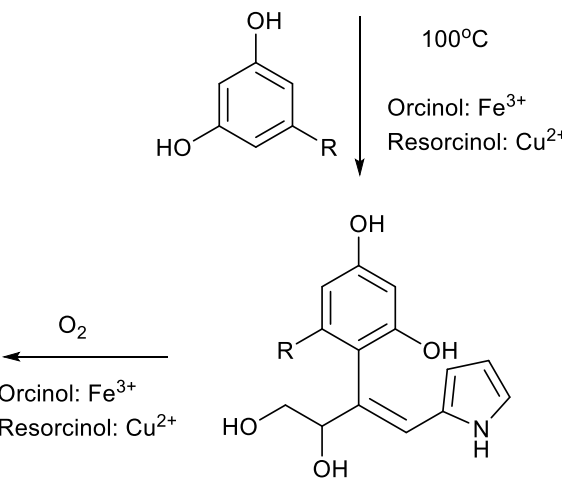

3 Orcinol $\mathrm{R}=\mathrm{H}$

4 Resorcinol $\mathrm{R}=\mathrm{CH}_{3}$

Scheme 1: Conversion of sialic acid to reactive intermediate 2 via reaction with strong acid

\subsection{Resorcinol}

This method, which builds on the orcinol method, was first reported by Svennerholm et al in 1947. Free sialic acids are reacted with the resorcinol reagent and this solution was produced by taking $10 \mathrm{~mL}$ of a solution containing $2 \mathrm{~g}$ resorcinol in $100 \mathrm{~mL}$ water and adding this to $80 \mathrm{~mL}$ of conc. $\mathrm{HCl}$ containing $0.25 \mathrm{~mL}$ of $0.1 \mathrm{M}$ copper sulphate solution. This solution was then made up to $100 \mathrm{~mL}$ using water. Heating at $110^{\circ} \mathrm{C}$ for 15 minutes allowed the sialic acid to reach maximum absorbency and eliminate as much interference as possible from other hexoses that also react with the resorcinol. Copper ions are used in $\mathrm{HCl}$ to give the reactive intermediate 2 . This then reacts with resorcinol to give a chromogen 4 (scheme 1) that can be extracted into amyl alcohol to give chromophore 5. The resulting chromophore absorbs at $450 \mathrm{~nm}$ and gives a blue colour that is unique to sialic acid, all other sugars give a different colour allowing for determination of sialic acid when other ketohexoses are present. Some interference from ketohexoses was still observed but this could be overcome by recording absorbance at a second maximum of $580 \mathrm{~nm}$. The authors still indicated that between $2-8 \%$ of the absorbance being measured was not from sialic acid when measuring at $580 \mathrm{~nm}$, this was considered to be due to interference from pentoses, uronic acids and 2-deoxy sugars. ${ }^{34,35}$ There have been many improvements developed for this method, to potentially solve some of 
the above issues. The first is the use of an acetate ion exchange resin to separate the sialic acid from other compounds that could interfere with the assay. ${ }^{36}$ The sialic acid, deprotonated by the acetate ions, bind to the ion exchange resin while all other compounds are eluted with water. The sialic acid can then be collected using acetic acid as an eluant to give a sample containing only sialic acid which can then be measured using the resorcinol method. A further improvement in the method involved changing the extraction solvent from butan-1-ol to a mixture of isoamyl alcohol and butyl acetate $15: 85 .{ }^{37}$ This solvent system has better specificity towards the sialic acid chromogen, increasing the specificity of the method by elimination of unwanted chromophores. Finally, Jourdian et al. found that including a periodic acid oxidation step before the acid hydrolysis allowed sialic acid to be oxidised and produce a chromophore with absorbance at $625 \mathrm{~nm}$. This method reportedly removed interference from other monosaccharides and as such increased specificity of the method. ${ }^{38}$

\subsection{Periodic acid/thiobarbiturate}

This method was reported by both Warren ${ }^{39}$ and Aminoff. ${ }^{40}$ Both methods use periodic acid dissolved in an acidic solution for oxidation of sialic acid to give aldehyde $\mathbf{6}$. The Warren method uses stronger acidic conditions, $9 \mathrm{M}$ phosphoric acid versus $0.125 \mathrm{M}$ sulfuric acid for the Aminoff method. Excess periodate is reduced with sodium arsenite, following this an acidic solution of thiobarbituric acid is added to give a chromophore 7 (scheme 2). The Warren method extracts the chromophore into cyclohexanone, Aminoff extracted into acidified butanol to give chromophore that can be read in a spectrophotometer at $550 \mathrm{~nm}$. Other studies have used solvents such as methylcellulose, ${ }^{41}$ acetone/ $/ \mathrm{HCl}^{42}$ and DMSO. ${ }^{43}$ As with other colorimetric methods, this method suffers from interference from other compounds. Interference is evident from 2-deoxyribose these can also form formyl pyruvic acid and thus can subsequently react with thiobarbituric acid. One such way to reduce interference is to measure at $532 \mathrm{~nm}$ which is the absorbance for deoxyribose allowing for it to be quantified and hence subtracted from the total obtained measurement. ${ }^{40}$ Furthermore, as shown with the resorcinol method, ion exchange resins can be used to isolate sialic acid from compounds that may interfere, but these increase the time to result. ${ }^{44}$ One final improvement established that using glucose as an inhibitor can reduce interference from deoxyribose, ${ }^{45}$ as it acts as a competitor for oxidation by periodic acid and forms different products, giving formaldehyde and formic acid. Thus, the glucose chromophore formed is entirely different from that of 
compound 7 and its absorbance does not overlap with that of the sialic acid chromophore giving more accurate results.

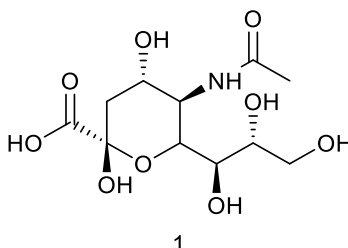

i. $\mathrm{HIO}_{4}$

ii. $\mathrm{H}^{+}, 100^{\circ} \mathrm{C}$

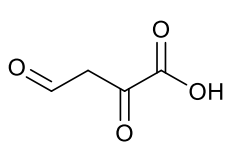

6

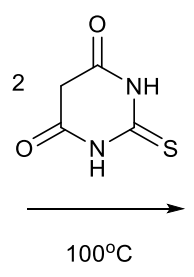<smiles>O=C(O)/C(=C\C=C1C(O)=NC(=S)N=C1O)c1c(O)nc(S)nc1O</smiles>

7

Scheme 2: Oxidation of sialic acid to give formylpyruvic acid and subsequent reaction with thiobarbituric acid

\subsection{Periodic acid/Methyl-3-benzothiazolinone-2-hydrazone (MBTH)}

Massamiri et al. reported this method in 1978 for the measurement of bound sialic acid directly without performing an acid hydrolysis step to first liberate bound sialic acid. ${ }^{46,47}$ This is possible by the direct release of formaldehyde $\mathbf{8}$ from bound sialic acid by the action of periodic acid in phosphate-buffered saline. The formaldehyde containing solution is reacted with zinc sulfate and $1 \mathrm{M} \mathrm{NaOH}$ followed by $\mathrm{MBTH}$ reagent in dilute $\mathrm{HCl}$ and $\mathrm{FeCl}_{3}$ (scheme 3). This reaction creates a bright green chromophore 9 that absorbs at $625 \mathrm{~nm}$. As this method avoids the need for an acid hydrolysis step, it requires less time to carry out than previously discussed methods. Formaldehyde can react with membrane surface amino groups to give Schiff bases, or diffuse into cells; the authors took this into account and determined that formaldehyde was not lost through these mechanisms during this analysis. Not mentioned in the article however is that formaldehyde is an endogenous molecule which could cause overestimation of sialic acid content. This assay was also utilised by Varki et al. for the determination of 9- $O$ acetylation of sialic $\operatorname{acid}^{48}$ because these derivatives are not oxidised to formaldehyde. Comparing the fluorescence intensity before and after an $O$ deacetylation step allowed measurement of the total 9-acetylation of sialic acid present. This was questioned by Shukla et al., however, when they utilised this method alongside an acetylacetone assay and this indicated that the values determined were rather variable and as such were unreliable. ${ }^{49}$ It was posited that this was due to interfering compounds that may also form formaldehyde under periodate oxidation conditions. 


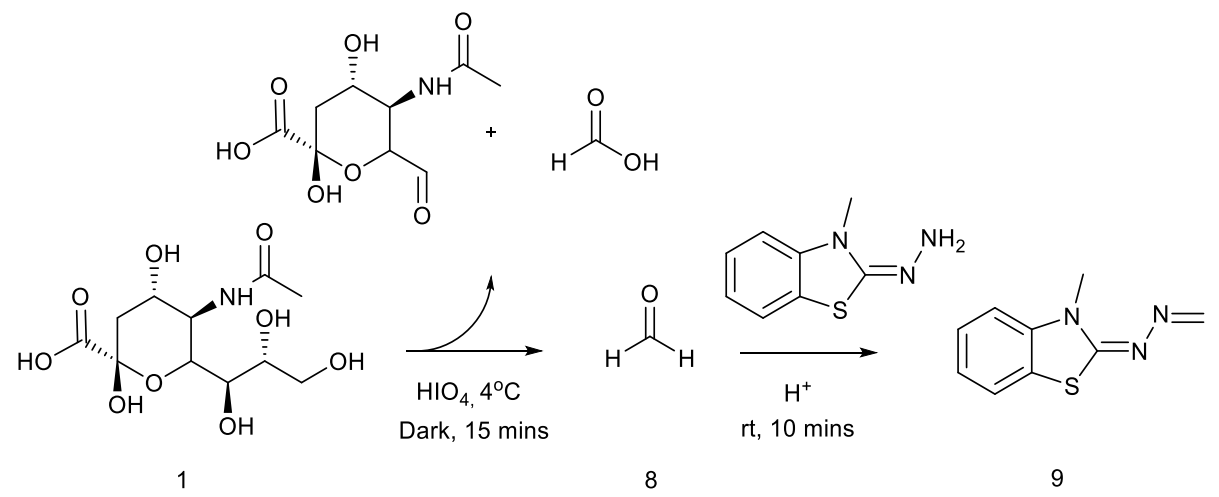

Scheme 3: Reaction of formylpyruvic acid and MBTH

\subsection{Summary}

Colorimetric methods (table 1) are often quick to perform and can generally be carried out in one pot reactions that do not require specialist facilities. These methods however may not be particularly sensitive or specific as hexoses, pentoses, deoxy sugars and ketohexoses are found to react with the reagents used alongside sialic acid. This culminates in the formation of multiple chromophores per reaction hence resulting in inaccurate quantitation. Some of these problems were overcome in later years but these advances resulted in more cumbersome procedures that could not fully mitigate all interferences. Moreover, the limit of detection of these methods is relatively high when compared to various other methods developed subsequently.

\begin{tabular}{|c|c|c|c|c|c|c|}
\hline Assay & Reagents & Advantages & Disadvantages & $\begin{array}{l}\text { Possible } \\
\text { interferences }\end{array}$ & $\begin{array}{l}\text { Limit of } \\
\text { detection }\end{array}$ & Ref \\
\hline Orcinol & $\begin{array}{l}\text { Orcinol, iron } \\
\text { (III) ions, } \mathrm{HCl}\end{array}$ & $\begin{array}{l}\text { Can measure } \\
\text { both free and } \\
\text { bound sialic } \\
\text { acid }\end{array}$ & $\begin{array}{l}\text { Not specific for } \\
\text { sialic acid }\end{array}$ & $\begin{array}{l}\text { Hexoses, } \\
\text { pentoses, } \\
\text { uronic acids }\end{array}$ & $\begin{array}{l}\text { Not } \\
\text { available }\end{array}$ & $\begin{array}{l}30- \\
33\end{array}$ \\
\hline Resorcinol & $\begin{array}{l}\text { Resorcinol, } \\
\text { Copper (II) } \\
\text { ions, } \mathrm{HCl}\end{array}$ & $\begin{array}{l}\text { Can measure } \\
\text { both free and } \\
\text { bound sialic } \\
\text { acid }\end{array}$ & $\begin{array}{l}\text { Not specific for } \\
\text { sialic acid }\end{array}$ & $\begin{array}{l}\text { Ketohexoses, } \\
\text { pentoses, 2- } \\
\text { deoxyhexoses }\end{array}$ & $\begin{array}{l}\text { Not } \\
\text { available }\end{array}$ & $\begin{array}{l}34- \\
38\end{array}$ \\
\hline Thiobarbiturate & $\begin{array}{l}\text { Periodic acid, } \\
\text { thiobarbituric } \\
\text { acid }\end{array}$ & $\begin{array}{l}\text { Can measure } \\
\text { both free and } \\
\text { bound sialic } \\
\text { acid without a } \\
\text { hydrolysis step. } \\
\text { Interference can } \\
\text { be reduced } \\
\text { through method } \\
\text { development }\end{array}$ & $\begin{array}{l}\text { Not specific for } \\
\text { sialic acid }\end{array}$ & $\begin{array}{l}2- \\
\text { Deoxyribose, } \\
\text { hexoses }\end{array}$ & $50 \mu \mathrm{g}$ & $\begin{array}{l}39- \\
45\end{array}$ \\
\hline $\begin{array}{l}\text { Methyl-3- } \\
\text { benzothiazolinone- } \\
\text { 2-hydrazone }\end{array}$ & $\begin{array}{l}\text { Periodic acid, } \\
\text { MBTH }\end{array}$ & $\begin{array}{l}\text { Can measure } \\
\text { free and bound } \\
\text { sialic acid } \\
\text { without } \\
\text { hydrolysis step. }\end{array}$ & $\begin{array}{l}\text { Not specific for } \\
\text { sialic acid }\end{array}$ & $\begin{array}{l}2- \\
\text { Deoxyribose, } \\
\text { hexoses }\end{array}$ & $\begin{array}{l}\text { Not } \\
\text { available }\end{array}$ & $\begin{array}{l}46- \\
49\end{array}$ \\
\hline
\end{tabular}


Table 2: Summary of colorimetric assays for sialic acid

\section{Fluorometric methods for the quantification of sialic acid}

Fluorometric methods for the analysis of sialic acid and its derivatives generally involve the reaction of sialic acid with an oxidant or acid whereupon the resulting compounds are reacted further to form a fluorophore. This is then excited, and the emission measured to determine the quantity of sialic acid present in a sample. Alternative complementary methods have also been developed wherein sialic acid is labelled with a fluorescent tag, forming a newly fluorescent compound. These methods were effective for the measurement of sialic acid but were notable to resolve different types of sialic acid from each other given that any derivatives of sialic acid are likely to form fluorophores that emit at the same maximum as sialic acid itself.

\subsection{3,5-Diaminobenzoic acid}

One of the first methods developed for the fluorometric analysis of sialic acid was reported by Hess and Rolde. ${ }^{28} 3,5$-diaminobenzoic acid is use a fluorescent tag to analyse sialic acid. This tag has previously been used as a fluorescent tag for the analysis of DNA, ${ }^{50}$ and also reacts with 2-deoxy sugars, aldehydes and hexoses to give fluorescent compounds. After considerable method development by the authors, the interference from other compounds, especially hexoses, was reduced to $1.6 \%$ by molar weight. This was achieved by adjusting the labelling reaction conditions based on the observations that in high concentrations of acid with heat, hexoses react to form compounds that react with 3,5-diaminobenzoic acid, and sialic acid is labile in hot dilute acid. As such, the authors undertook a search for conditions that would hydrolyse sialic acid and have a minimal effect on hexoses. The final reaction conditions involved the reduction of the concentration of 3,5-diaminobenzoic acid from $1 \mathrm{M}$ to $0.005 \mathrm{M}, \mathrm{HCl}$ from $4 \mathrm{M}$ to $0.125 \mathrm{M}$ and increasing the reaction time under heating from 1.5 to 16 hours. This had an effect wherein sialic acid was hydrolysed and successfully labelled, while a minimum quantity of interfering compounds reacted with the 3-5diaminobenzoic acid. The label could effectively be used to label $5 \mu \mathrm{mol}$ of sialic acid per $100 \mu \mathrm{L}$ of 3,5-diaminobenzoic acid solution, any amount of sialic acid above this requires more labelling reagent or some labelling efficacy is lost resulting in inaccurate results. This method is highly specific for sialic acid and therefore provides accurate results in the quantification of sialic acids in human samples, and in this case specifically brain gangliosides. 


\subsection{Thiobarbiturate method}

A slight modification for the thiobarbiturate method discussed in the previous section was identified that allowed for fluorometric rather than colorimetric analysis of sialic acid. ${ }^{51}$ The method is initially the same, wherein sialic acids are released from glycans using mild acid hydrolysis and then reacted with thiobarbituric acid, in this case a fluorogen is formed rather than a chromogen. This fluorogen, when extracted into acidified butanol, gives a fluorophore that can be excited at $550 \mathrm{~nm}$, giving an emission at $570 \mathrm{~nm}$. This method was found to be more sensitive than the traditional thiobarbiturate method by a factor of 500, allowing for analysis of sialic acid in the picomole range. Although more sensitive for sialic acid, this approach still suffers from the same issues as the colorimetric thiobarbiturate method, with interference from numerous other compounds, giving inaccurate results and indicating poor specificity for sialic acid.

\subsection{Pyridoxamine}

This method was developed by Murayama and colleagues as a more sensitive method for sialic acid analysis that could determine sialic acid in quantities as low as $0.1 \mu \mathrm{g}{ }^{52}$ Pyridoxamine dihydrochloride $\mathbf{9}$ in the presence of zinc acetate and pyridine in methanol heated at $70^{\circ} \mathrm{C}$ for 45 minutes reacts with $\alpha$-keto acid resulting from ring opening of sialic acid to give a fluorophore $\mathbf{1 2}$ (scheme 4). The authors report that the method could be utilised to determine amounts of sialic acid between 1-10 $\mu \mathrm{g}$ using $250 \mu \mathrm{g}$ of pyridoxamine, incomplete labelling was seen in amounts of sialic acid above $10 \mu \mathrm{g}$. Due to the nature of this reaction, it cannot react with sialic acids substituted at the 2-position, as such bound sialic acid must be first released via acid hydrolysis or enzymatic action. As such, this method is specific for free sialic acid, but bound sialic acid can also be measured by performing a prior acid release step. This method does suffer from interference from $\alpha$-keto acids which will react with pyridoxamine in a 1:1 ratio. As such, care must be taken to remove these from a sample prior to analysis which can in some cases be either difficult or not possible.
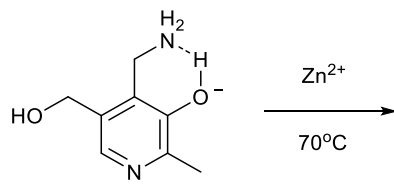

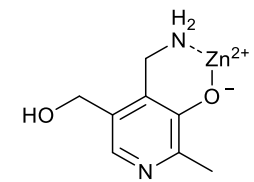

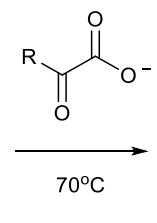

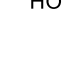

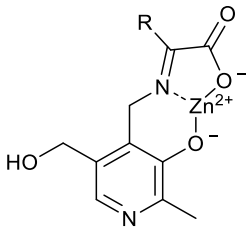

11

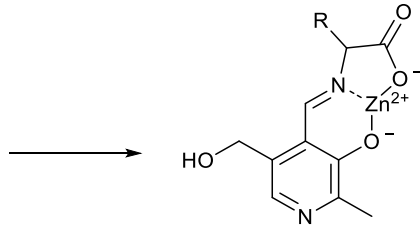

12

Scheme 4: Reaction of formylpyruvic acid with pyridoxamine in the presence of zinc ions 


\subsection{Acetylacetone/Periodic acid}

This method involves the oxidation of bound sialic acid with periodic acid to form formaldehyde 8, which when reacted with an acetylacetone $\mathbf{1 3}$ solution (acetylacetone, ammonium acetate, glacial acetic acid and distilled water) at $60^{\circ} \mathrm{C}$ for 10 minutes gives a fluorescent compound $\mathbf{1 4}$ (scheme 5) that emits at $510 \mathrm{~nm} .{ }^{49}$ This method was found to be as sensitive as the previously mentioned thiobarbiturate method modification and the pyridoxamine method, being able to measure roughly $0.1 \mu \mathrm{g}$ of sialic acid requiring $300 \mu \mathrm{L}$ of labelling solution taken from a stock solution $(200 \mu \mathrm{L}$ acetylacetone, $15 \mathrm{~g}$ ammonium acetate, $300 \mu \mathrm{L}$ glacial acetic acid, $99.5 \mathrm{~mL}$ water). It was observed that for free sialic acid this method was comparable to that of the orcinol and thiobarbituric assays. The authors also noted an excellent use for this assay, in that it could be used to quantify $O$-acetylated sialic acid. 4- $O$ Acetylated sialic acids are oxidised under the conditions utilised by the authors whilst 8 and 9- $O$ acetylated and 8,9-di- $O$ acetylated sialic acid do not react, as they are not oxidised by periodic acid and therefore do not react with acetylacetone to give a fluorophore. The amount of 8 and $9 O$-acetylation present can be determined by subjecting the sample to an $O$-deacetylation procedure using $0.1 \mathrm{M} \mathrm{NaOH}$ prior to derivatising the sialic acid present. The increase in fluorogenic activity gives the quantity of acetylation present in the sample in total. In terms of interference, the authors report that endogenous formaldehyde did not interfere with the reported method. Interferences were found however from other compounds that give formaldehyde: free monosaccharides and oligosaccharides, and diols. The authors also stated to avoid the use of tris buffers as this can form formaldehyde, and to use the buffer stated in the paper to avoid this issue.

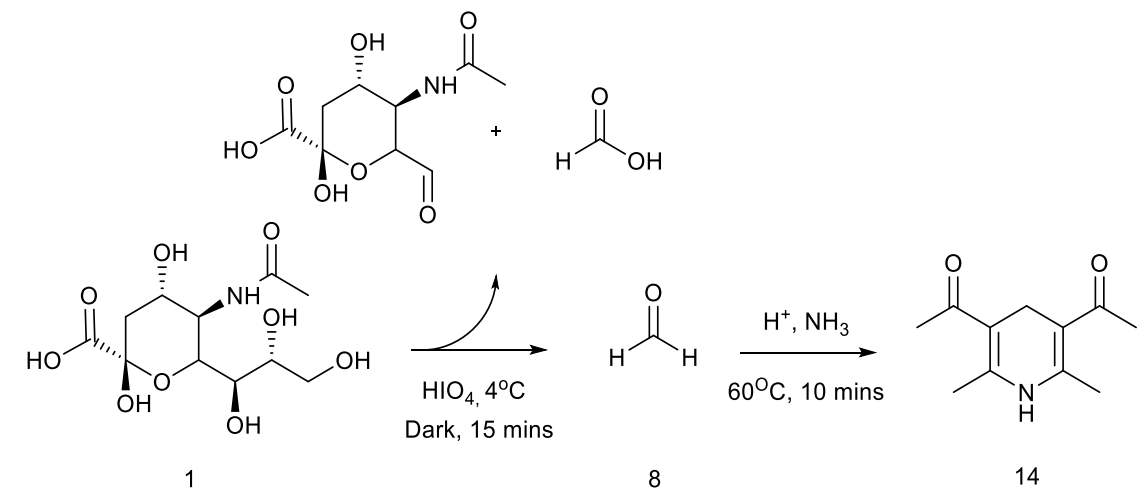

Scheme 5: Reaction of formaldehyde with acetylacetone and ammonia 


\subsection{Acetoacetanilide/Ammonia}

This method was developed much more recently than most other fluorometric methods and was first reported in 2008 for the analysis of sialic acid bound to glycoproteins. Formaldehyde $\mathbf{8}$ is generated by oxidisation of sialic acid with periodic acid. Excess periodate is neutralised by the addition of sodium thiosulfate as opposed to sodium arsenite due to concerns regarding its toxicity. This is followed by subsequent formation of a fluorophore $\mathbf{1 6}$ (scheme 6) by reaction with acetanilide $\mathbf{1 5}$ and ammonium acetate at room temperature for 10 minutes. ${ }^{53}$ This gives a compound that when excited at $388 \mathrm{~nm}$ emits at $471 \mathrm{~nm}$. This method is extremely sensitive, being able to measure quantities of sialic acid as low as $1 \mu \mathrm{g}$ and as high as $90 \mu \mathrm{g}$. The authors stated however that amounts of sialic acid above this upper limit showed incomplete labelling. This method is specific for sialic acid given that the authors tested the assay on aldohexoses and methyl alpha-D-glucoside which formed a pyranose ring that did not react with acetoacetinilide. The authors report that linear polyalcohols, such as sorbitol (derived from gluose), form two units of formaldehyde and therefore react with acetoacetanilide and show twice the fluorescence of sialic acid. These polyalcohols are not likely to occur in most analyses unless the sample to analysed is taken from fruits.

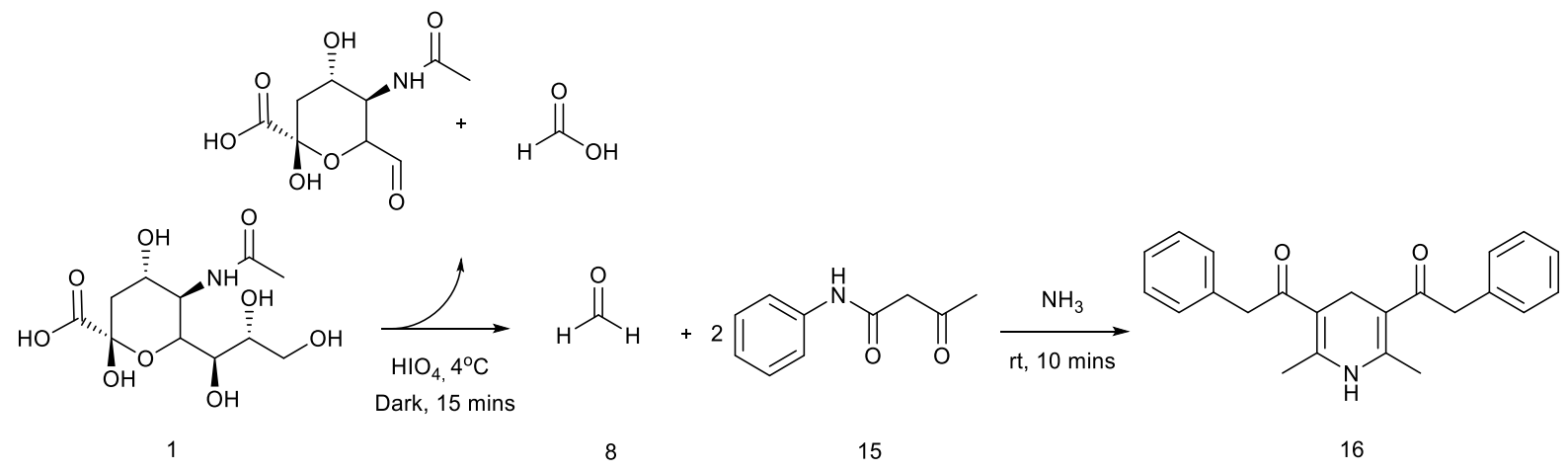

Scheme 6: Reaction of formaldehyde with acetanilide and ammonia

\subsection{Summary}

Fluorometric methods (table 2) offer some advantages over colorimetric methods previously discussed. Less interference is found with these methods, fewer compounds react with the selected reagents alongside sialic acid. Higher sensitivity is also found, with methods being roughly 500 times more sensitive than colorimetric methods. These methods can take a long time to perform, however, generally requiring hydrolysis and labelling steps that can take up to 48 hours which is not favourable if a large number of samples needs to be analysed or 
there is a time constraint. They are still easy to perform, similar to colorimetric methods, meaning any laboratory could reasonably utilise these methods without much preparation or specialist equipment.

\begin{tabular}{|c|c|c|c|c|c|c|}
\hline Assay & Reagents & Advantages & Disadvantages & $\begin{array}{l}\text { Possible } \\
\text { interferences }\end{array}$ & $\begin{array}{l}\text { Limit of } \\
\text { detection }\end{array}$ & $\operatorname{Ref}$ \\
\hline $\begin{array}{l}3,5- \\
\text { Diaminobenzoic } \\
\text { acid }\end{array}$ & $\begin{array}{l}3,5- \\
\text { Diaminobenzoic } \\
\text { acid, } \mathrm{HCl}\end{array}$ & & $\begin{array}{l}\text { Not specific for } \\
\text { sialic acid } \\
\text { (modification of } \\
\text { reaction } \\
\text { conditions can } \\
\text { overcome this } \\
\text { somewhat) }\end{array}$ & $\begin{array}{l}\text { 2-Deoxy } \\
\text { sugars, } \\
\text { aldehydes, } \\
\text { hexoses }\end{array}$ & $\begin{array}{l}\text { Not } \\
\text { available }\end{array}$ & $\begin{array}{l}27 \\
50\end{array}$ \\
\hline Thiobarbiturate & $\begin{array}{l}\text { Periodic acid, } \\
\text { thiobarbituric } \\
\text { acid }\end{array}$ & $\begin{array}{l}\text { High } \\
\text { sensitivity }\end{array}$ & $\begin{array}{l}\text { Not specific for } \\
\text { sialic acid }\end{array}$ & $\begin{array}{l}2- \\
\text { Deoxyribose, } \\
\text { hexoses } \\
\end{array}$ & $0.1 \mu \mathrm{g}$ & 51 \\
\hline Pyridoxamine & $\begin{array}{l}\text { Pyridoxamine, } \\
\text { zinc acetate and } \\
\text { pyridine }\end{array}$ & $\begin{array}{l}\text { High } \\
\text { sensitivity }\end{array}$ & $\begin{array}{l}\text { Does not react } \\
\text { with 2-position } \\
\text { substituted sialic } \\
\text { acids }\end{array}$ & $\alpha$-ketoacids & $0.1 \mu \mathrm{g}$ & 52 \\
\hline Acetylacetone & $\begin{array}{l}\text { Periodic acid, } \\
\text { acetylacetone, } \\
\text { sodium arsenite }\end{array}$ & $\begin{array}{l}\text { High } \\
\text { sensitivity } \\
\text { Can be used } \\
\text { to measure } \\
\text { degree of } O \text { - } \\
\text { acetylated } \\
\text { sialic acids. }\end{array}$ & $\begin{array}{l}\text { Highly toxic } \\
\text { reagents }\end{array}$ & $\begin{array}{l}\text { Endogenous } \\
\text { pyruvate }\end{array}$ & $0.1 \mu \mathrm{g}$ & 49 \\
\hline Acetoacetanilide & $\begin{array}{l}\text { Periodic acid, } \\
\text { acetanilide, } \\
\text { ammonia }\end{array}$ & $\begin{array}{l}\text { Extremely } \\
\text { sensitive. } \\
\text { Very specific } \\
\text { for sialic acid. }\end{array}$ & & $\begin{array}{l}\text { Endogenous } \\
\text { pyruvate }\end{array}$ & $1 \mu \mathrm{g}$ & 53 \\
\hline
\end{tabular}

Table 3: Summary of fluorometric assays for sialic acid

\section{Enzymatic methods for the analysis of sialic acid}

Enzymatic methods for the analysis of sialic acid are interesting in that they offer new methods for analysis as well as methods that complement previously developed methods. These generally involve the cleavage of sialic acid from glycans and glycoproteins followed by the transformation of the released sialic acid into other compounds such as pyruvate and hydrogen peroxide that can subsequently be measured either colorimetrically or by a variety of other methods. These methods are effective in their measurement of sialic acid present in a sample, no ability to distinguish between sialic acid and its derivatives was evident in the literature however. 


\section{1 $N$-Acetyl-D-mannosamine/Pyruvate}

One of the first methods identified for the quantitation of sialic acid via an enzymatic method utilised the reaction of sialic acid with sialic acid aldolase. This enzyme catalyses the reversible formation of $\mathrm{N}$-acetyl-D-mannosamine $\mathbf{1 7}$ and pyruvate $\mathbf{1 8}$ from sialic acid (scheme 7). This gives two options for determining the sialic acid content of a biological sample. The first option is monitoring the formation of $N$-acetyl-D-mannosamine by the action of sodium tetraborate and 4-dimethylaminobenzaldehyde. ${ }^{54}$ This gives a chromophore that emits at $582 \mathrm{~nm}$ which can be used to quantify sample sialic acid. This method has a downside in that it is quite cumbersome to perform, requiring a long time for the formation of the chromophore, it does not suffer from interference from other compounds however due to the specificity of the enzyme for sialic acid and the lack of endogenous $N$-acetyl-Dmannosamine.

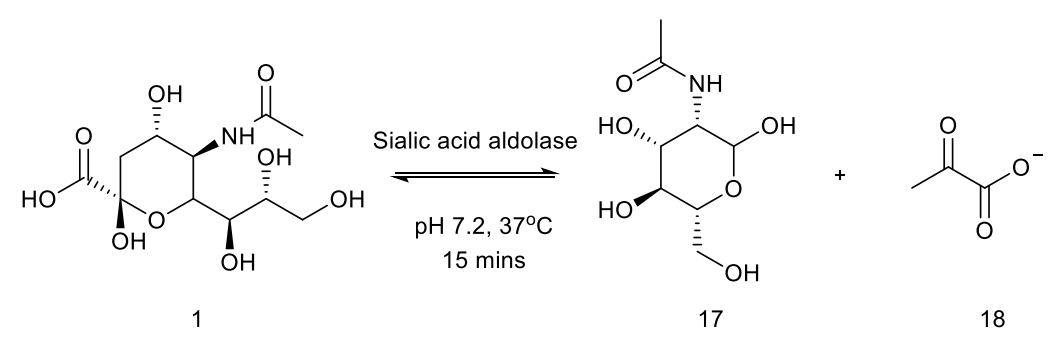

Scheme 7: Reversible reaction of sialic acid to $N$-acetyl-D-mannosamine

The second option is the formation of pyruvate which can be measured by utilising lactate dehydrogenase and NADH. NADH is oxidised in this reaction with pyruvate and by measuring the level of NADH oxidation photometrically at $340 \mathrm{~nm}$, the amount of pyruvate can be quantified and therefore so can sialic acid. ${ }^{55}$ This method can suffer from interference from endogenous pyruvate, leading to results that are higher than anticipated, this can be accounted for by creating a standard curve of pyruvate concentrations. One advantage is found in that this method can be used to accurately quantify sialic acid in large quantities of sample. In samples containing sialic acid at concentrations of $1 \mathrm{mmol}$ or less the conversion of sialic acid reaches completion, this is however not usually the case for larger quantities of sample. The use of NADH and lactate dehydrogenase does however drive the reaction to completion even for large numbers of samples, allowing for more accurate quantitation. This method was also performed using enzymes that were immobilised on a polymer support, this gave good reusability of the enzymes. ${ }^{56}$ 
A similar method to this was devised that avoided pyruvate and long reaction times, wherein $\mathrm{N}$-acetyl-D-mannosamine was converted to $\mathrm{N}$-acetyl-2-aminomannonic acid by the action of amine dehydrogenase and $\mathrm{NAD}^{+}$, which is reduced to NADH. This change can also be tracked at $340 \mathrm{~nm}$ to give the quantity of sialic acid present. ${ }^{57}$ This method also offers the advantage of avoiding interference from other compounds due to the lack of endogenous $\mathrm{N}$ acetyl-D-mannosamine.

\subsection{Pyruvate/Hydrogen Peroxide}

A further method for sialic acid analysis that builds on the previous protocol converts the pyruvate, that is liberated by the action of sialic acid aldolase, into hydrogen peroxide. This is performed by utilising pyruvate oxidase. Subsequent colorimetric determination of hydrogen peroxide is then achieved with 4-chlorophenol, 4-aminoantipyrine and peroxidase. ${ }^{58}$ This has also been carried out using 4-animoantipyrine and $N$-ethyl- $N$-2-hydroxyethyl-3-toluidine. ${ }^{59}$

The method was markedly improved upon by circumventing the issue of endogenous pyruvate interference. This was achieved by using sialic acid aldolase, $N$-acylglucosamine epimerase, $\mathrm{N}$-acetyl hexosamine oxidase and peroxidase. This converts sialic acid to $\mathrm{N}$ acetyl-D-mannosamine 17, followed by $N$-acetyl-D-glucosamine 19 and subsequently hydrogen peroxide $\mathbf{2 1}$ is released (scheme 8). The hydrogen peroxide is then converted to a colorimetrically active compound via the action of peroxidase. ${ }^{60}$ This overcomes endogenous pyruvate interference since hydrogen peroxide is released from $\mathrm{N}$-acetyl hexosamine as opposed to pyruvate. The method has a disadvantage however in that it is very cumbersome to perform, involving four enzymes, and requiring a large time commitment compared to other methods. It will however provide accurate results as it suffers from no interferences from other compounds present in the sample. 


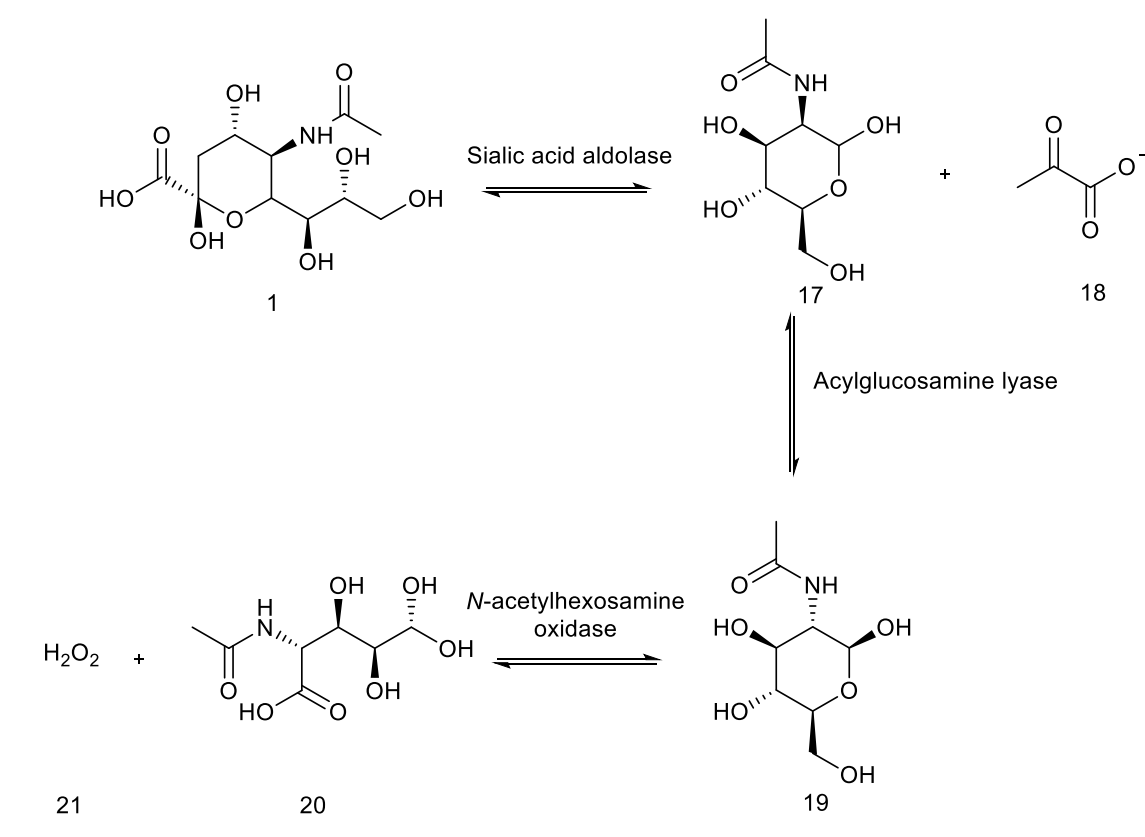

Scheme 8: Reversible reaction of sialic acid to $N$-acetyl-D-mannosamine, followed by $N$-acetyl-D-glucosamine, finally to release of hydrogen peroxide. This reaction is carried in one-pot at $37^{\circ} \mathrm{C}$ for 10 minutes in a $\mathrm{pH} 7.5$ tris buffer.

Both methods utilise colorimetry to determine the concentration of sialic acid, another method developed much later utilises a biosensor to detect the hydrogen peroxide produced. ${ }^{61}$ This will be more expensive than other methods to perform, it will however be quicker and possibly more accurate.

\subsection{Cholerae sialidase/resorcinol}

Sialic acid is generally found as the terminal monosaccharide unit in the oligosaccharide chain bound by $\alpha-2,3$ and $\alpha-2,6$ linkages. ${ }^{25}$ As discussed, these can be liberated by the action of acid or enzyme and are prone to oxidation by reagents such as periodic acid. Some sialic acid is found however as an $\alpha-2,8$ linked 'internal' sialic acid ${ }^{25}$ but this is not released either by the action of acid or enzymes such as aldolases and the $\alpha-2,8$ linkages are resistant to oxidation, ${ }^{62}$ which affects quantitation by many methods, especially those using periodic acid or other oxidising agents such as the resorcinol or thiobarbiturate methods. This was overcome by releasing the sialic acid by the action of $V$. cholerae sialidase which breaks these $\alpha-2,8$ linkages and therefore releases all sialic acid in the sample from glycoconjugates. ${ }^{63}$ The authors then subjected sialic acid to quantitation by the resorcinol method. This however suffers from the usual drawbacks of this method leading to poor results, as such, combining this method with a different method for quantitation is pertinent to receive accurate results. 


\subsection{Summary}

Enzymatic assays (table 3) for sialic acid are exceptionally specific for sialic acid due to the specificity of enzymes. Some interference can be found however from compounds that are themselves products of these enzymatic reactions; pyruvate is one such case. These methods however can be very cumbersome to perform requiring multiple steps and long reaction and incubation times. Enzymes can also be expensive to purchase and may only be available in small quantities. This may allow only a few samples to be analysed at any given time. Overall, these methods are very useful with the specificity and sensitivity perhaps outweighing the time commitment required to perform them.

\begin{tabular}{|c|c|c|c|c|c|c|}
\hline Assay & Reagents & Advantages & Disadvantages & $\begin{array}{l}\text { Possible } \\
\text { interferences }\end{array}$ & $\begin{array}{l}\text { Limit of } \\
\text { detection }\end{array}$ & Ref \\
\hline $\begin{array}{l}\text {-Acetyl-D- } \\
\text { mannosamine } \\
\text { measurement }\end{array}$ & $\begin{array}{l}N \text {-Acetyl } \\
\text { neuraminic acid } \\
\text { aldolase }\end{array}$ & $\begin{array}{l}\text { Highly } \\
\text { specific }\end{array}$ & $\begin{array}{l}\text { Cumbersome } \\
\text { to perform, } \\
\text { long reaction } \\
\text { times. }\end{array}$ & N/A & $\begin{array}{l}\text { Not } \\
\text { available }\end{array}$ & 54 \\
\hline $\begin{array}{l}\mathrm{NADH} \\
\text { measurement }\end{array}$ & $\begin{array}{l}N \text {-acetyl neuraminic } \\
\text { acid aldolase, } \\
\text { lactate } \\
\text { dehydrogenase, } \\
\text { NADH }\end{array}$ & $\begin{array}{l}\text { Highly } \\
\text { specific. Can } \\
\text { measure large } \\
\text { quantities of } \\
\text { sialic acid in } \\
\text { samples }\end{array}$ & & Pyruvate & $\begin{array}{l}\text { Not } \\
\text { available }\end{array}$ & $\begin{array}{l}36- \\
37\end{array}$ \\
\hline $\begin{array}{l}\mathrm{NAD}^{+} \\
\text {measurement }\end{array}$ & $\begin{array}{l}N \text {-acetyl neuraminic } \\
\text { acid aldolase, amine } \\
\text { dehydrogenase and } \\
\mathrm{NAD}^{+}\end{array}$ & $\begin{array}{l}\text { Highly } \\
\text { specific }\end{array}$ & $\begin{array}{l}\text { Cumbersome } \\
\text { due to the use } \\
\text { of many } \\
\text { different } \\
\text { enzymes }\end{array}$ & N/A & $\begin{array}{l}\text { Not } \\
\text { available }\end{array}$ & $\begin{array}{l}55- \\
58\end{array}$ \\
\hline $\begin{array}{l}\text { Hydrogen Peroxide, } \\
\text { colorimetric } \\
\text { measurement }\end{array}$ & $\begin{array}{l}N \text {-acetyl neuraminic } \\
\text { acid aldolase, } \\
\text { pyruvate oxidase }\end{array}$ & $\begin{array}{l}\text { Highly } \\
\text { specific }\end{array}$ & & Pyruvate & $\begin{array}{l}\text { Not } \\
\text { available }\end{array}$ & $\begin{array}{l}58 \\
59\end{array}$ \\
\hline $\begin{array}{l}\text { Hydrogen peroxide, } \\
\text { avoiding } \\
\text { interference }\end{array}$ & $\begin{array}{l}N \text {-acetyl neuraminic } \\
\text { acid aldolase, } N \text { - } \\
\text { acetylglucosamine } \\
\text { epimerase, } N \text {-acetyl } \\
\text { hexosamine oxidase } \\
\text { and peroxidase }\end{array}$ & $\begin{array}{l}\text { Incredibly } \\
\text { specific for } \\
\text { sialic acid, no } \\
\text { interference } \\
\text { reported }\end{array}$ & $\begin{array}{l}\text { Very } \\
\text { cumbersome to } \\
\text { perform } \\
\text { requiring many } \\
\text { enzymes }\end{array}$ & N/A & $\begin{array}{l}\text { Not } \\
\text { available }\end{array}$ & 60 \\
\hline $\begin{array}{l}\text { Hydrogen peroxide } \\
\text { biosensor }\end{array}$ & $\begin{array}{l}\text { Same as above, } \\
\text { with an electronic } \\
\text { biosensor for } \\
\text { measurement }\end{array}$ & $\begin{array}{l}\text { Incredibly } \\
\text { specific for } \\
\text { sialic acid, no } \\
\text { interference } \\
\text { reported. } \\
\text { More accurate } \\
\text { due to } \\
\text { electronic } \\
\text { measurement }\end{array}$ & $\begin{array}{l}\text { Very } \\
\text { cumbersome to } \\
\text { perform } \\
\text { requiring many } \\
\text { enzymes }\end{array}$ & N/A & $\begin{array}{l}\text { Not } \\
\text { available }\end{array}$ & 61 \\
\hline $\begin{array}{l}\text { V. Cholerae } \\
\text { sialidase/resorcinol }\end{array}$ & $\begin{array}{l}\text { V. cholerae, } \\
\text { periodic acid, } \\
\text { resorcinol }\end{array}$ & $\begin{array}{l}\text { Can measure } \\
\text { all sialic acid } \\
\text { in a sample, } \\
\text { highly } \\
\text { specific }\end{array}$ & $\begin{array}{l}\text { Usual } \\
\text { drawbacks of } \\
\text { resorcinol } \\
\text { method }\end{array}$ & N/A & $\begin{array}{l}\text { Not } \\
\text { available }\end{array}$ & 62 \\
\hline
\end{tabular}


Table 4: Summary of enzymatic assays for sialic acid

\section{Chromatographic and mass spectrometric assays for the determination of sialic acid}

Most recently chromatography has been employed to provide a means for the separation, identification and subsequent quantification of sialic acids in biological ${ }^{64-66}$ and other samples such as infant formula ${ }^{67}$ and milk products. ${ }^{68}$ For the analysis of sialic acids, derivatisation is required using fluorescent labels and reverse phase chromatography is employed to separate the sialic acids from the bulk material and from each other, allowing closer scrutiny of a variety of sialic acid derivatives in one sample. This separation is then followed by measurement of the sugars present by use of methods such as UV detection, mass spectrometry or fluorescence detection.

\subsection{Early chromatographic assays}

The earliest methods developed for the chromatographic determination of sialic acids utilised gas chromatography (GC), gas chromatography-mass spectrometry (GC-MS) and high performance liquid chromatography (HPLC) coupled with UV detection. ${ }^{69-71}$ The GC and HPLC methods proved to not be particularly sensitive, being unable to detect small biological quantities of sialic acids, and only able to carry out quantification on large quantities of standard samples. The GC-MS methods are much more sensitive than the GC or HPLC methods, and are able to measure smaller quantities of sialic acids, $20 \mathrm{pmol}$, but it is a very cumbersome method requiring many instruments to carry out the procedure and as such it may be preferable to utilise a different assay. As such, these methods were generally overlooked in favour of other methods utilising other HPLC method combinations.

\subsection{Combination with colorimetric assays}

One such example is the combination of HPLC with the previously discussed thiobarbiturate method. ${ }^{44}$ The sample is reacted with periodic acid and thiobarbiturate to give chromophores of sialic acid and other compounds. Combining this with HPLC allows for separation of the chromophores from one another to give only sialic acid chromophores that can then be quantified to give more accurate results. This method still suffers from the issue that it is quite cumbersome, taking a long time to perform, and it utilises highly toxic chemicals such as sodium arsenite. ${ }^{40}$ 


\subsection{Derivatization of sialic acid with fluorescent tags}

Another way of analysing sialic acids involves releasing sialic acid from glycans via hydrolysis to give the reactive species 22 (schemes 9, 10 and 11) and then these are labelled to give a fluorescently active species. This can then be detected using fluorescent detection. This has been used previously to analyse total sialic acid, as discussed in the fluorometric section of this paper, but by combining with HPLC the compounds can be separated and analysed more readily with less interference from other compounds allowing for identification and possible quantitation of derivatives of sialic acid.

4-Hydrazino-2-stilbazole is a reagent for $\alpha$-keto acids (scheme 9). The authors identified that $10 \mathrm{mM}$ of 4-hydrazino-2-stilbazole in $0.5 \mathrm{M}$ ammonium chloride solution gave the most fluorescent compound 23 after heating $0.1 \mathrm{~mL}$ of plasma that had been subjected to acid hydrolysis at $85^{\circ} \mathrm{C}$ for 15 minutes in the dark. ${ }^{72}$ These derivatised compounds were then applied to an HPLC column to allow for separation. Peaks for Neu5Ac and Neu5Gc could be identified by the compound's emission maximum at $550 \mathrm{~nm}$. Other $\alpha$-keto acids present in human plasma had a retention time longer than that of sialic acid and as such did not compromise the efficiency of this method. Pyruvate and two unknown peaks were identified however, showing that this method is not as highly specific for sialic acid as hoped and has disadvantages in that the unknown peaks overlap somewhat with the sialic acid peaks on the HPLC trace causing some inaccuracy in the quantitation of the sialic acid as the peak areas will be larger than anticipated. The authors also reported that the fluorophore formed is very unstable, offering only 2 hours of stability in the dark post labelling and is not stable for any length of time under light.

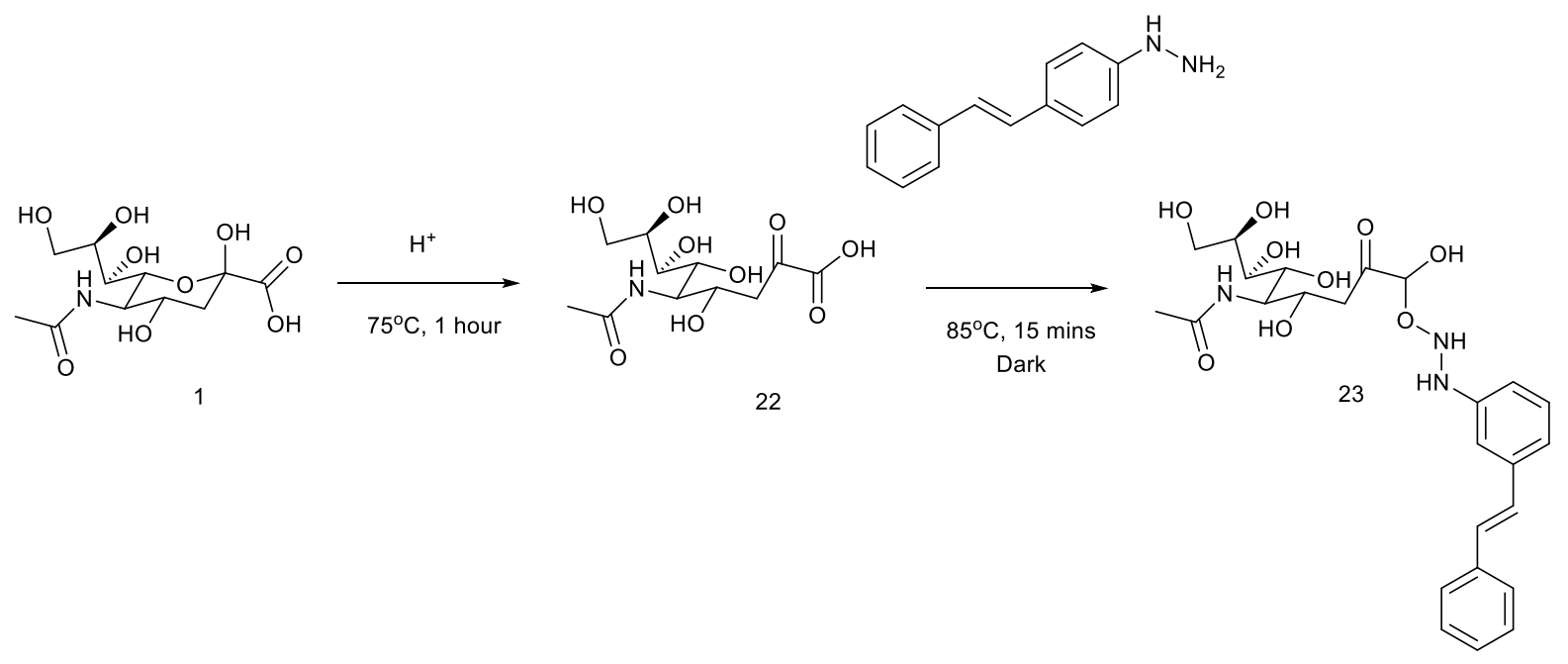


Alkaline borate buffers ( $\mathrm{pH}$ 10) can be used to form sialic acid borate complexes that when combined with malononitrile give a fluorescent compound. ${ }^{73,74}$ Separation was achieved on a reverse phase column to give good separation of sialic acids. There were many other compounds also labelled with the malononitrile however, such as aldoses, ketoses, deoxy sugars and amino sugars. As such, interference is highly likely. This method offers one major advantage in that it is very quick to carry out as it can also be performed using post-column labelling. The sugars are first separated, the HPLC eluant is mixed with malononitrile and this gives fluorescent compounds that can be quantified while avoiding lengthy labelling and clean up procedures. This method can be fully automatic, requiring much less time and user input. Using post-column labelling also aids in the avoidance of interference from non-sialic acids because the sialic acid borate complexes are retained on the column for longer than potentially interfering substances.

Phenyldiamine. $2 \mathrm{HCl}$ was also identified as a candidate for labelling of sialic acids (scheme 10) giving a fluorophore $\mathbf{2 5},{ }^{75}$ this method was found however to take an extremely long time, 48 hours at room temperature, which could be reduced to 16 hours at $37{ }^{\circ} \mathrm{C}$. The authors did not comment on other compounds that may interfere with this method, they did comment however on additional peaks found on HPLC traces that did not correspond to sialic acid or sialic acid derivatives and as such it would appear that this label is not particularly sensitive for sialic acid.
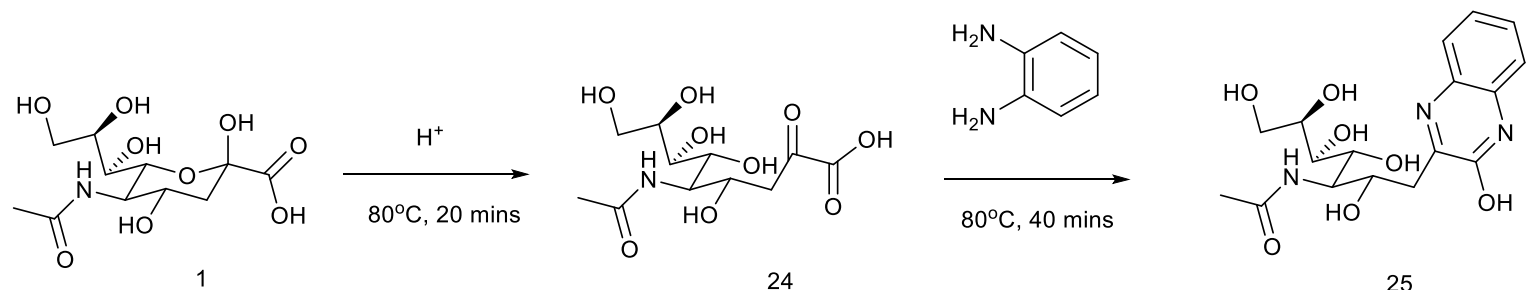

Scheme 10: Hydrolysis of sialic acid and reaction with phenyldiamine

1,2-Diamino-4,5-methyleneoxybenzene (DMB) is perhaps the most widely explored and utilised labelling reagent. Sialic acid and its derivatives that have been liberated from glycoproteins can be labelled with DMB using mercaptoethanol and sodium hydrosulfite using water as a solvent by heating for $50^{\circ} \mathrm{C}$ for 2 hours (scheme 11) to give a fluorophore 27. Glyosidic bonds and the sialic acids are hydrolysed using a variety of acids at low concentrations. Sulfuric acid, ${ }^{76,77} 0.1 \mathrm{M} \mathrm{TFA},{ }^{78}$ formic $\operatorname{acid}^{79}$ and $2 \mathrm{M}$ acetic acid ${ }^{80}$ have been used to perform this hydrolysis using $70-80{ }^{\circ} \mathrm{C}$ heat. $2 \mathrm{M}$ acetic acid is the preferable reagent due to the fact that the other acids can cause cleavage or migration of $O$-acetyl groups on $O$ - 
acetylated sialic acid derivatives. Leaving these intact is preferable as this allows for analysis of a wider variety of sialic acids. The downside of using acetic acid over any other hydrolysis agent is the time required for full release of all sialic acids, 3 hours at $80^{\circ} \mathrm{C}$ compared to times of 1 hour or less for other stronger acids.

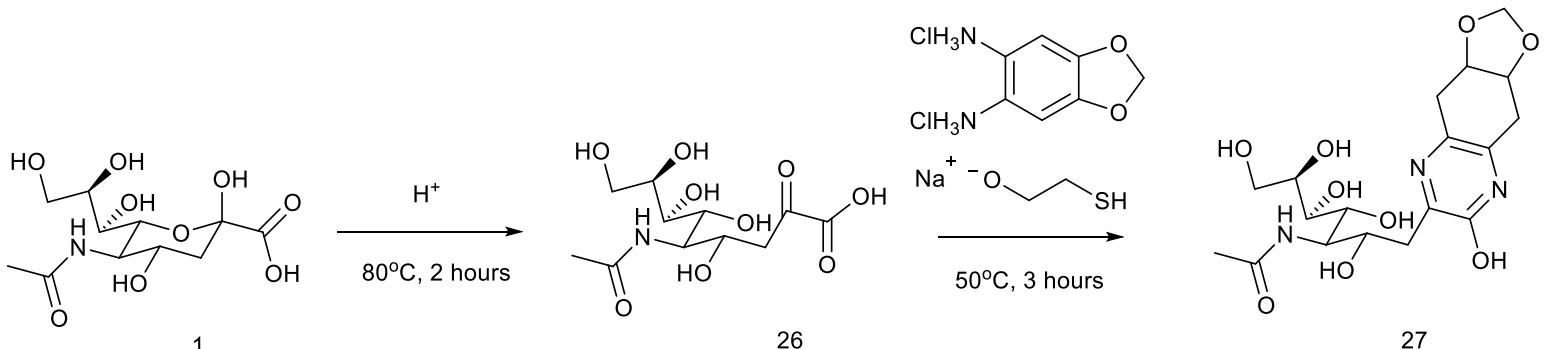

Scheme 11: Acid hydrolysis of sialic acid followed by DMB labelling

Authors have reported zero interference from compounds other than sialic acid and its derivatives when labelling with DMB is used. This is due to its high selectivity for the diketone species formed when sialic acid is hydrolysed under mildly acidic conditions. The method is very specific and is also highly sensitive with studies reporting detection limits of sialic acids as low as $12 \mathrm{pg}$ to as high as $0.46 \mathrm{ng} .{ }^{76,78,80,81}$ One study reported the lower limit of detection as $0.3 \mathrm{mg}$ but this appears to be due to the fact that this was the lowest size standard sample used by the authors and it appears that further validation with smaller sample quantities could be carried out. ${ }^{79}$

DMB labelling has one disadvantage in that the derivatized sialic acids are not very stable for periods over 24 hours; they are only stable for hours at room temperature ${ }^{82}$ and are sensitive to UV light. This means that the samples must undergo analysis promptly after derivatisation, the samples have been shown to be stable for up to 24 hours in the dark at $4{ }^{\circ} \mathrm{C} .{ }^{77}$ This can pose a problem when the samples may be held in an autosampler to be analysed for periods longer than 24 hours dependent on the run time per sample and number of samples to be analysed at one time. This has the potential to pose problems of sample stability and as such could interfere with accurate quantitation of sialic acid and its derivatives when utilising these methods. One possible method for overcoming this is the utilisation of UHPLC methods to decrease run time, limiting the amount of time the samples are held in unfavourable conditions thereby limiting degradation of DMB derivatized sialic acids.

A further major disadvantage of the above methods is the way by which the sialic acids are identified and quantified. This is performed by using internal standards for identification by 
comparing retention times and the creation of standard calibration curves for quantification. This requires the ability to purchase or synthesise standards of the compounds to be analysed, Neu5Ac is readily available, with Neu5Gc being available in smaller quantities. There is however a lack of availability of other derivatives of Neu5Ac and Neu5Gc. These must be synthesised either enzymatically or chemically which can be exceedingly difficult to perform and may not be possible to carry out on the scale at which it is required for analysis. As such, analysing Neu5Ac and Neu5Gc may be relatively easy, but it is much more difficult to analyse and quantify other derivatives, for example $O$-acetylated sialic acids.

Some work has been carried out in this area however, groups have made use of a reference panel of different sialic acids mixed together for the purpose of identifying sialic acids in biological samples by the comparison of retention times of acetylated sialic acid derivatives extracted from bovine submaxillary mucin. This has been put to good use in analysing the $O$ acetylated derivatives present in dried blood spots by DMB analysis. ${ }^{83}$ The usage is limited to identification of sialic acids however and separate synthesis or extraction of $O$-acetylated derivatives from biological samples is required for accurate quantitation.

\subsection{Liquid chromatography-mass spectrometry (LC-MS)}

Building on these chromatographic methods, is the use of LC-MS of unmodified sugars. ${ }^{84}$ Sugars are subjected to acid hydrolysis to break glyosidic bonds after which they are applied to an LC system for separation and these compounds are then introduced into a mass spectrometry system wherein each compound is profiled, and sialic acids are identified using internal standards of Neu5Ac and Neu5Gc. This is a relatively sensitive method, able to detect quantities as small as $10 \mathrm{ng}$. There are no interference considerations as all compounds were shown to be efficiently separated and detected by MS.

More recent advances in LC-MS assays have utilised tandem MS/MS methods both in isolation ${ }^{85-89}$ and in combination with $\mathrm{LC}^{90}$ for the identification and quantification of sialic acid, sialic acid derivatives ${ }^{90}$ and sialic acid containing oligo and polysaccharides. ${ }^{86,88,89}$ Not only can specific structures be elucidated, but the method can also be effective without the use of internal standards. Internal standards are still required for quantification via these methods, however. ${ }^{90,91}$ These methods utilise two mass spectrometers in tandem. The first instrument ionises the samples and separates ions by mass-to-charge $(\mathrm{m} / \mathrm{z})$ ratio. A predetermined set of ions are then selected for analysis via the second spectrometer wherein they are fragmented, and the resulting mass data can be analysed. ${ }^{92}$ 
To ensure that sialic acid is efficiently ionised, some steps are required to ensure minimal loss of sample, sufficient ionisation for analysis and to protect the carboxylic acid groups present in sialic acid so that they do not form salts with sodium, potassium and ammonium ions which can affect the measured masses and make identification of sialic acid species difficult. To overcome these issues, the sialic acids are derivatised in a number of different ways to protect the carboxylic acid. First among these is protecting the carboxylic acid through nonlinkage specific derivatisation methods, chief and simplest among these is the use of methyl iodide for methyl protection of the carboxylic acid. Other derivatisations, such as amidation of the carboxylic acid can be carried out in the presence of an amine and an appropriate condensing agent. ${ }^{93}$ This carboxylic acid protection can also be carried by lactonization of sialic acid by esterification of the carboxylic acid. ${ }^{86}$ Lastly, the sialic acid chains can be derivatised at the reducing end to then give compounds that can be separated by HPLC methods and then fed into an MS/MS system for analysis after separation from compounds not wanted for analysis. This also helps with ionisation of the compounds due to increased hydrophobicity and therefore ionisation efficiency in the mass spectrometer. ${ }^{94}$

This method also boasts the ability to differentiate between different sialic acid linkages by linkage specific derivatisation. Generally, this is derivatisation of both $\alpha-2,3$ and $\alpha-2,6$ sialic acid followed by lactone formation in only $\alpha-2,3$ sialic acid giving different masses based on linkage. This can provide interesting information in the context of the action of certain viruses which are linkage specific such as flu viruses wherein human flu viruses prefer $\alpha-2,6$ linkages ${ }^{95}$ and animal viruses prefer $\alpha-2,3$ linkages $^{96}$ of sialic acid when binding to cells.

\subsection{Summary}

Chromatographic methods (table 4) offer many advantages in that interferences are not an issue with these methods due to the ability to separate sialic acid from other compounds in biological samples. These methods do require a large time commitment however as with run times varying between 10-30 minutes, a 96-well plate of samples can require up to 48 hours for analysis. This time does not include any preparation and labelling time. One other major disadvantage of these methods is the need for internal standards for the construction of standard curves for quantification of different derivatives of sialic acids. Finally, the instrumentation to carry out these analyses can be prohibitively expensive to obtain and as such may prove out of reach for some researchers attempting analyses of sialic acid.

\begin{tabular}{|l|l|l|l|l|l|l|}
\hline Assay & Reagents & Advantages & Disadvantages & $\begin{array}{l}\text { Possible } \\
\text { interference }\end{array}$ & $\begin{array}{l}\text { Limit of } \\
\text { detection }\end{array}$ & Ref \\
\hline
\end{tabular}




\begin{tabular}{|l|l|l|l|l|l|l|}
\hline $\begin{array}{l}\text { 4-Hydrazino-2- } \\
\text { stillbazole }\end{array}$ & $\begin{array}{l}\text { 4-Hydrazino-2- } \\
\text { stillbazole }\end{array}$ & $\begin{array}{l}\text { Allows } \\
\text { separation } \\
\text { from } \\
\text { Neu5Ac }\end{array}$ & $\begin{array}{l}\text { Pyruvate and } \\
\text { other unknown } \\
\text { compound } \\
\text { interference }\end{array}$ & $\begin{array}{l}\text { Pyruvate and } \\
\text { as of yet } \\
\text { unidentified } \\
\text { compounds }\end{array}$ & $\begin{array}{l}\text { Not } \\
\text { available }\end{array}$ & 72 \\
\hline Malononitrile & $\begin{array}{l}\text { Malononitrile, } \\
\text { borate buffer }\end{array}$ & $\begin{array}{l}\text { Very quick, } \\
\text { using post } \\
\text { column } \\
\text { labelling }\end{array}$ & $\begin{array}{l}\text { Interference is } \\
\text { highly likely }\end{array}$ & $\begin{array}{l}\text { Not } \\
\text { available }\end{array}$ & 73,74 \\
\hline Phenyldiamine.2HCl & $\begin{array}{l}\text { Phenyldiamine, } \\
\text { NaHSO }\end{array}$ & $\begin{array}{l}\text { Highly } \\
\text { specific for } \\
\text { sialic acid }\end{array}$ & $\begin{array}{l}\text { Extremely long } \\
\text { reaction time } \\
\text { Not particularly } \\
\text { sensitive }\end{array}$ & N/A & $\begin{array}{l}\text { Not } \\
\text { available }\end{array}$ & 75 \\
\hline DMB & $\begin{array}{l}\text { DMB, sodium } \\
\text { mercaptoethanol }\end{array}$ & $\begin{array}{l}\text { Leaves } O- \\
\text { acetyl } \\
\text { derivatives } \\
\text { intact } \\
\text { Zero } \\
\text { interference } \\
\text { due to highly } \\
\text { selective } \\
\text { fluorescent } \\
\text { tag }\end{array}$ & $\begin{array}{l}\text { Fluorophore is } \\
\text { not stable under } \\
\text { standard } \\
\text { conditions }\end{array}$ & N/A & $\begin{array}{l}12 \text { pg- } \\
0.46 \text { ng }\end{array}$ & $\begin{array}{l}76- \\
83\end{array}$ \\
\hline LC-MS & $\begin{array}{l}\text { Relatively } \\
\text { high } \\
\text { sensitivity }\end{array}$ & $\begin{array}{l}\text { High } \\
\text { sensitivity } \\
\text { and no } \\
\text { issues } \\
\text { arising from } \\
\text { specificity }\end{array}$ & $\begin{array}{l}\text { Expensive } \\
\text { instrumentation } \\
\text { required }\end{array}$ & N/A & $\begin{array}{l}\text { Not } \\
\text { available }\end{array}$ & $\begin{array}{l}\text { 85- } \\
96\end{array}$ \\
\hline LC-MS/MS & & N/A & $\begin{array}{l}\text { Not } \\
\text { available }\end{array}$ & 84 \\
\hline
\end{tabular}

Table 5: Summary of chromatographic assays for sialic acid

\section{Future Prospects}

Development of assays for the detection of sialic acid is by no means a completed area of research; there is still much possibility for improvement. As discussed in this review, the most widely used fluorescent tag for sialic acid detection, DMB, is not stable for more than 24 hours in light at room temperature and it must be stored at $-20^{\circ} \mathrm{C}$ in the dark to avoid degradation. This is neither favourable for the analysis of large batches of samples nor for long term storage. As such, the discovery, validation and implementation of more stable fluorescent dyes would be a particularly important step towards facilitating analysis and quantification of sialic acid. Recent research has identified 4,5-dimethylbenzene-1,2-diamine (DMBA) as a labelling reagent ${ }^{97-99}$ that is similar to those previously discussed but does not suffer from the same instability post-derivatisation, whilst offering similar labelling times to DMB and still offering excellent UV and fluorescent activity for detection and measurement. Room for improvement can also be found in the length of time required to analyse a batch of 
samples. Run times vary based on the affinity of the labelled derivatives for the column material, the column used (eg particulate size and column length can be varied) and the mobile phase. These conditions can greatly affect the time it takes to run a sample on HPLC. If a large batch of samples is to be analysed, a long run time can cause issues with throughput. Changing the aforementioned variables, and making usage of ultra-high-pressure liquid chromatography, as compared to HPLC, can significantly reduce run times allowing for greater throughput and analysis of large batches of samples in a shorter time span. ${ }^{100,101}$ Another possible improvement is the utilisation of microtiter plate-based assays. Most previous assays for sialic acid that use DMB and similar dyes utilise screw cap vials to perform the labelling and other required reactions prior to analysis. Microtiter plates offer a plausible alternative in that a greater number of samples can be analysed in a shorter span of time, especially when combined with the use of multi-channel pipettes or liquid handling robots. This increases throughput by allowing for more than one sample to be prepared at a time as opposed to vials which need to be handled individually. As a consequence, there is also a reduction in errors that may occur due to cross-contamination or sample inversion, due to easier coding of the wells or the use of automated systems. Further to this, replacing the usage of HPLC equipment with fluorescence-based plate readers could increase the speed of analysis for sialic acids. This has been used successfully for sialic acid analysis, ${ }^{102-104}$ and, as such, fluorescence detection plate reader sialic acid analysis methods that complement or even replace the use of HPLC based methods, could now be probed. Finally, further usage of tandem MS/MS methods especially in conjunction with HPLC methods could be used to identify and elucidate the structures of not only monosaccharide units of sialic acid but also sialic acid polysaccharides and sialic acid containing oligosaccharides. This could allow for expansion of the field to search for changes in sialylation during different disease states such as cancer and conditions exhibiting inflammation where this hypersialylation is most prevalent. These analyses could provide data on different derivatisations of sialic acid, acetylation for example, or different sialic acid linkages that are observed and how these are caused by or are responsible for a given disease state.

\section{Conclusions}

The many different assays for sialic acid detection and quantification discussed herein offer a wide range of options for the quantification and possible identification of sialic acid and its derivatives in biological samples. Colorimetric and fluorometric methods offer the advantages of being quick, simple and cheap to perform. These methods do not require many 
reagents, and these are themselves readily available, they are also generally one pot reactions requiring only a handful of hours to carry out the procedure. They are, however, not particularly specific for sialic acid, with interferences from other sugars present in samples such as other hexoses, pentoses, ketohexoses and deoxy sugars. They may be preferable however to enzymatic, chromatographic and mass spectrometric methods which require expensive reagents and equipment, as well as a large time commitment. The advantage of these methods however is seen in the specificity and accuracy of the results as well as the high sensitivity making these excellent candidates for the analysis of sialic acids in biological samples. The usage of enzymatic, chromatographic and mass spectrometric methods has wide ranging implications for the analysis of sialic acid in biological samples for biomarker analysis. It becomes possible to validate sialic acid as a potential biomarker for health conditions such as cardiovascular disease and cancer, secure in the knowledge that interferences from other compounds have been eliminated, paving the way for improvements in early detection and diagnosis of these diseases.

\section{Acknowledgments}

Financial support from the MRC and Ludger Ltd (MR/P015786/1) to JC, is gratefully acknowledged.

\section{References}

1. Varki A. Diversity in the sialic acids. Glycobiology. 1992;2(1):25-40. doi:10.1093/glycob/2.1.25

2. Varki A, Cummings RD, Esko JD, et al. Essentials of Glycobiology, Third Edition. Cold Spring Harbor Laboratory Press; 2017.

3. Varki A. Sialic acids in human health and disease. Trends Mol Med. 2008;14(8):351360. doi:10.1016/j.molmed.2008.06.002

4. Schauer R. Sialic acids and their role as biological masks. Trends Biochem Sci. 1985;10(9):357-360. doi:10.1016/0968-0004(85)90112-4

5. Kumlin U, Olofsson S, Dimock K, Arnberg N. Sialic acid tissue distribution and influenza virus tropism. Influenza Other Respi Viruses. 2008;2(5):147-154. doi:10.1111/j.1750-2659.2008.00051.x 
6. Leung HSY, Li OTW, Chan RWY, Chan MCW, Nicholls JM, Poon LLM. Entry of Influenza A Virus with a 2,6-Linked Sialic Acid Binding Preference Requires Host Fibronectin. J Virol. 2012;86(19):10704-10713. doi:10.1128/jvi.01166-12

7. Schauer R. Sialic acids as regulators of molecular and cellular interactions. Curr Opin Struct Biol. 2009;19(5):507-514. doi:10.1016/j.sbi.2009.06.003

8. Zhou X, Yang G, Guan F. Biological Functions and Analytical Strategies of Sialic Acids in Tumor. Cells. 2020;9(2):273. doi:10.3390/cells9020273

9. Råstam L, Lindberg G, Folsom AR, Burke GL, Nilsson-Ehle P, Lundblad A. Association between serum sialic acid concentration and carotid atherosclerosis measured by B-mode ultrasound. The ARIC Investigators. Atherosclerosis Risk in Communities Study. Int J Epidemiol. 1996;25(5):953-958.

10. Lindberg G, Råstam L, Gullberg B, Eklund GA. Serum sialic acid concentration predicts both coronary heart disease and stroke mortality: Multivariate analysis including 54385 men and women during 20.5 years follow-up. Int J Epidemiol. 1992;21(2):253-257. doi:10.1093/ije/21.2.253

11. Gavella M, Lipovac V, Car A, Vučić M, Sokolić L, Rakoš R. Serum sialic acid in subjects with impaired glucose tolerance and in newly diagnosed type 2 diabetic patients. Acta Diabetol. 2003;40(2):95-100. doi:10.1007/s005920300012

12. Rajaram S, Danasekaran B, Venkatachalapathy R, Prashad K, Rajaram S. Nacetylneuraminic acid: A scrutinizing tool in oral squamous cell carcinoma diagnosis. Dent Res J (Isfahan). 2017;14(4):267-271. doi:10.4103/1735-3327.211621

13. Habibi S, Jamshidian H, Kadivar M, et al. A study of lipid- and protein- bound sialic acids for the diagnosis of bladder cancer and their relationships with the severity of malignancy. Reports Biochem Mol Biol. 2014;2(2):70-75.

14. Goodarzi MT, Shafiei M, Nomani H, Shahriarahmadi A. Relationship Between Total and Lipid-bound Serum Sialic Acid and Some Tumor Markers. Iran J Med Sci. 2015;30(3):124-127.

15. Krishnan K, Balasundaram S. Estimation of total and lipid bound sialic acid in serum in oral leukoplakia. J Clin Diagnostic Res. 2017;11(3):ZC25-ZC27. doi:10.7860/JCDR/2017/16483.9497 
16. Nigam PK, Narain VS, Kumar A, Nigam PK. Sialic acid in cardiovascular diseases. Indian J Clin Biochem. 2006;21(1):54-61. doi:10.1007/BF02913067

17. Crook MA, Scott DA, Stapleton JA, Palmer RM, Wilson RF, Sutherland G.

Circulating concentrations of C-reactive protein and total sialic acid in tobacco smokers remain unchanged following one year of validated smoking cessation. Eur $J$ Clin Invest. 2000;30(10):861-865. doi:10.1046/j.1365-2362.2000.00738.x

18. Wu EB, Lumb P, Chambers JB, Crook MA. Plasma sialic acid and coronary artery atheromatous load in patients with stable chest pain. Atherosclerosis. 1999;145(2):261266. doi:10.1016/S0021-9150(99)00074-X

19. Crook MA, Tutt P, Simpson H, Pickup JC. Serum sialic acid and acute phase proteins in type 1 and type 2 diabetes mellitus. Clin Chim Acta. 1993;219(1-2):131-138. doi:10.1016/0009-8981(93)90204-h

20. Crook MA, Tutt P, Pickup JC. Elevated serum sialic acid concentration in NIDDM and its relationship to blood pressure and retinopathy. Diabetes Care. 1993;16(1):57-60. doi:10.2337/diacare.16.1.57

21. Afzali B, Bakri RS, Bharma-Ariza P, et al. Raised plasma total sialic acid levels are markers of cardiovascular disease in renal dialysis patients. $J$ Nephrol. 2003;16(4):540-545.

22. Pickup JC, Roberts GA, Kehely AM, Pasapula C, Chusney GD, Mather HM. Higher serum sialic acid in women than in men with NIDDM: Possible relevance to increased cardiovascular risk in NIDDM women [2]. Diabetes Care. 1997;20(9):1496. doi:10.2337/diacare.20.9.1496

23. Zhang C, Yan L, Song H, et al. Elevated serum sialic acid levels predict prostate cancer as well as bone metastases. J Cancer. 2019;10(2):449-457.

doi:10.7150/jca.27700

24. Verazin G, Riley WM, Gregory J, Tautu C, Prorok JJ, Alhadeff JA. Serum sialic acid and carcinoembryonic levels in the detection and monitoring of colorectal cancer. Dis Colon Rectum. 1990;33(2):139-142. doi:10.1007/bf02055544

25. Schauer R, Kamerling JP. Exploration of the Sialic Acid World. In: Advances in Carbohydrate Chemistry and Biochemistry. Vol 75. Academic Press Inc.; 2018:1-213. 
doi:10.1016/bs.accb.2018.09.001

26. Ayala W, Moore L V., Hess EL. The purple color reaction given by diphenylamine reagent. I. With. J Clin Invest. 1951;30(7):781-785. doi:10.1172/JCI102492

27. Werner I, Odin L. On the presence of sialic acid in certain glycoproteins and in gangliosides. Acta Soc Med Ups. 1952;57(3-4):230-241.

28. Hess H, Rolde E. Fluorometric assay of sialic acid in brain gangliosides. J Biol Chem. 1964;239:3215-3220.

29. Folch J, Arsove S, Meath JA. Isolation of brain strandin, a new type of large molecule tissue component. J Biol Chem. 1951;191(2):819-831.

30. Hess EL, Coburn AF, Bates RC, Murphy P. A new method for measuring sialic acid levels in serum and its application to rheumatic fever. J Clin Invest. 1957;36(3):449455. doi:10.1172/JCI103442

31. Klenk, E Langerbeins H. Orcinol method for measuring sialic acid. Hoppe-Seyler's Z Physiol. 1941;270:185-193.

32. Li J, Kisara K, Danielsson S, Lindström ME, Gellerstedt G. An improved methodology for the quantification of uronic acid units in xylans and other polysaccharides. Carbohydr Res. 2007;342(11):1442-1449. doi:10.1016/j.carres.2007.03.031

33. Peters BP, Aronson NN. Reactivity of the sialic acid derivative 5-acetamido-3,5dideoxy-L-arabino-heptulosonic acid in the resorcinol and thiobarbituric acid assays. Carbohydr Res. 1976;47(2):345-353. doi:10.1016/S0008-6215(00)84204-4

34. Svennerholm L. Quantitive estimation of sialic acids. II. A colorimetric resorcinolhydrochloric acid method. BBA - Biochim Biophys Acta. 1957;24(C):604-611. doi:10.1016/0006-3002(57)90254-8

35. Svennerholm L. Assay of Sialic Acids. Methods Enzytool. 1963;6:459-462.

36. Svennerholm L. Quantative Estimation of Sialic Acids. Acta Chem Scand. 1958;3:547554.

37. Takki-Luukeainen TM and IT. Use of Butyl Acetate in Determination of Sialic Acid. Acta Chem Scand. 1959;13:856-858. 
38. Jourdian GW, Dean L, Roseman S. The sialic acids. XI. A periodate-resorcinol method for the quantitative estimation of free sialic acids and their glycosides. $J$ Biol Chem. $1971 ; 246(2): 430-435$.

39. Aminoff D. The determination of free sialic acid in the presence of the bound compound. Virology. 1959;7(3):355-357. doi:10.1016/0042-6822(59)90207-7

40. Warren L. The thiobarbituric acid assay of sialic acids. J Biol Chem. 1959;234(8):1971-1975.

41. Uchida Y, Tsukada Y, Sugimori T. Distribution of neuraminidase in Arthrobacter and its purification by affinity chromatography. J Biochem. 1977;82(5):1425-1433. doi:10.1093/oxfordjournals.jbchem.a131830

42. Saifer A, Gerstenfeld S. Photometric determination of sialic acids in serum and cerebrospinal fluid with the thiobarbituric acid method. Clin Chim Acta. 1962;7(4):467-475. doi:10.1016/0009-8981(62)90086-4

43. Skoza L, Mohos S. Stable thiobarbituric acid chromophore with dimethyl sulphoxide. Application to sialic acid assay in analytical de $\mathrm{O}$ acetylation. Biochem $\mathrm{J}$. 1976;159(3):457-462. doi:10.1042/bj1590457

44. Krantz MJ, Lee YC. A sensitive autoanalytical method for sialic acids. Anal Biochem. 1975;63(2):464-469. doi:10.1016/0003-2697(75)90370-X

45. Smith CH, Donohue TM, Depper R. Glucose suppression of deoxyribose interference in the thiobarbituric acid determination of sialic acid. Anal Biochem. 1975;67(1):290297. doi:10.1016/0003-2697(75)90296-1

46. Durand G, Feger J, Coignoux M, Agneray J, Pays M. Rapid estimation of small amounts of formaldehyde liberated during periodate oxidation of a sialoglycoprotein. Anal Biochem. 1974;61(1):232-236. doi:10.1016/0003-2697(74)90349-2

47. Massamiri Y, Durand G, Richard A, Féger J, Agneray J. Determination of erythrocyte surface sialic acid residues by a new colorimetric method. Anal Biochem. 1979;97(2):346-351. doi:10.1016/0003-2697(79)90084-8

48. Varki A, Kornfeld S. An autosomal dominant gene regulates the extent of 9-Oacetylation of murine erythrocyte sialic acids. A probable explanation for the variation in capacity to activate the human alternate complement pathway. J Exp Med. 
1980;152(3):532-544. doi:10.1084/jem.152.3.532

49. Shukla AK, Schauer R. Fluorimetrische bestimmung von unsubstituierter bzw. 9(8)-oacetylierter sialimäure in ery throzy tenmembranen. Hoppe Seylers Z Physiol Chem. 1982;363(1):255-262. doi:10.1515/bchm2.1982.363.1.255

50. M. Pesez. Analytic Differentiation of Ribo- And Thymo-Nucleic Acids. Bull Soc Chim Biol. 1950;32(9-10):701-702.

51. Hammond KS, Papermaster DS. Fluorometric assay of sialic acid in the picomole range: A modification of the thiobarbituric acid assay. Anal Biochem. 1976;74(2):292297. doi:10.1016/0003-2697(76)90210-4

52. Murayama JI, Tomita M, Tsuji A, Hamada A. Fluorimetric assay of sialic acids. Anal Biochem. 1976;73(2):535-538. doi:10.1016/0003-2697(76)90204-9

53. Matsuno K, Suzuki S. Simple fluorimetric method for quantification of sialic acids in glycoproteins. Anal Biochem. 2008;375(1):53-59. doi:10.1016/j.ab.2008.01.002

54. Brunetti P, Jourdian GW, Roseman S. The sialic acids. III. Distribution and properties of animal N-acetylneuraminic aldolase. J Biol Chem. 1962;237:2447-2453.

55. Brunetti P, Swanson A, Roseman S. [68] Enzymatic determination of sialic acids. Nacylneuraminic acid $\rightleftarrows \mathrm{N}$-acyl-d-mannosamine + pyruvate. Methods Enzymol. 1963;6(C):465-473. doi:10.1016/0076-6879(63)06208-X

56. Kolisis FN. An immobilized bienzyme system for assay of sialic acid. Biotechnol Appl Biochem. 8(2-3):148-152.

57. Horiuchi T, Kurokawa T. New enzymatic endpoint assay of serum sialic acid. Clin Chim Acta. 1989;182(1):117-121. doi:10.1016/0009-8981(89)90156-3

58. Sugahara K, Sugimoto K, Nomura O, Usui T. Enzymatic assay of serum sialic acid. Clin Chim Acta. 1980;108(3):493-498. doi:10.1016/0009-8981(80)90360-5

59. Simpson H, Chusney GD, Crook MA, Pickup JC. Serum sialic acid enzymatic assay based on microtitre plates: application for measuring capillary serum sialic acid concentrations. Br J Biomed Sci. 1993;50(2):164-167.

60. Teshima S, Tamai K, Hayashi Y, Emi S. New enzymatic determination of sialic acid in serum. Clin Chem. 1988;34(11):2291-2294. 
61. Marzouk SAM, Ashraf SS, Al Tayyari KA. Prototype Amperometric Biosensor for Sialic Acid Determination. Anal Chem. 2007;79(4):1668-1674.

doi:10.1021/ac061886d

62. Ledeen RW, Yu RK. [10] Gangliosides: Structure, Isolation, and Analysis. Methods Enzymol. 1982;83(C):139-191. doi:10.1016/0076-6879(82)83012-7

63. Maliakal MA, Ravindranath MH, Irie RF, Morton DL. An improved method for the measurement of total lipid-bound sialic acids after cleavage of $\alpha 2,8$ sialic acid linkage with Vibrio cholerae sialidase in the presence of cholic acid, SDS and Ca2+. Glycoconj J. 1994;11(2):97-104. doi:10.1007/BF00731149

64. Yeşilyurt B, Şahar U, Deveci R. Determination of the type and quantity of sialic acid in the egg jelly coat of the sea urchin Paracentrotus lividus using capillary LC-ESIMS/MS. Mol Reprod Dev. 2015;82(2):115-122. doi:10.1002/mrd.22448

65. Cavdarli S, Dewald JH, Yamakawa N, et al. Identification of 9-O-acetyl-Nacetylneuraminic acid (Neu5,9Ac 2 ) as main O-acetylated sialic acid species of GD2 in breast cancer cells. Glycoconj J. 2019;36(1):79-90. doi:10.1007/s10719-018-09856$\mathrm{W}$

66. Thomson RI, Gardner RA, Strohfeldt K, et al. Analysis of Three Epoetin Alpha Products by LC and LC-MS Indicates Differences in Glycosylation Critical Quality Attributes, Including Sialic Acid Content. Anal Chem. 2017;89(12):6455-6462. doi:10.1021/acs.analchem.7b00353

67. Hurum DC, Rohrer JS. Determination of sialic acids in infant formula by chromatographic methods: A comparison of high-performance anion-exchange chromatography with pulsed amperometric detection and ultra-high-performance liquid chromatography methods. J Dairy Sci. 2012;95(3):1152-1161. doi:10.3168/jds.2011-4988

68. Tang K-T, Liang L-N, Ya-Qi C, Shi-Fen M. Determination of Sialic Acid in Milk and Products Using High Performance Anion-Exchange Chromatography Coupled with Pulsed Amperometric Detection. Vol 36.; 2008. doi:10.1016/S1872-2040(09)60005-0

69. Shukla AK, Scholz N, Reimerdes EH, Schauer R. High-performance liquid chromatography of N,O-acylated sialic acids. Anal Biochem. 1982;123(1):78-82. 
doi:10.1016/0003-2697(82)90625-X

70. Shukla AK, Schauer R. Analysis of N,O-acylated neuraminic acids by highperformance liquid anion-exchange chromatography. J Chromatogr A. 1982;244(1):81-89. doi:10.1016/S0021-9673(00)80124-7

71. Silver HKB, Karim KA, Gray MJ, Salinas FA. High-performance liquid chromatography quantiation of $\mathrm{n}$-acetylneuraminic acid in malignant melanoma and breast carcinoma. J Chromatogr B Biomed Sci Appl. 1981;224(3):381-388. doi:10.1016/S0378-4347(00)80210-8

72. Kobayashi K, Akiyama Y, Kawaguchi K, Tanabe S, Imanari T. Fluorometric determination of $\mathrm{N}$-acetyl and $\mathrm{N}$-glycolyl neuraminic acids by high performance liquid chromtography as their 4'-hydrazino-2-stilbazole derivatives. Anal Sci. 1985;1(1):8184. doi:10.2116/analsci.1.81

73. Honda S, Iwase S, Suzuki S, Kakehi K. Fluorometric determination of sialic acids using malononitrile in weakly alkaline media and its application to postcolumn labeling in high-performance liquid chromatography. Anal Biochem. 1987;160(2):455461. doi:10.1016/0003-2697(87)90075-3

74. Li K. Determination of sialic acids in human serum by reversed-phase liquid chromatography with fluorimetric detection. J Chromatogr B Biomed Sci Appl. 1992;579(2):209-213. doi:10.1016/0378-4347(92)80384-3

75. Anumula KR. Rapid quantitative determination of sialic acids in glycoproteins by high- performance liquid chromatography with a sensitive fluorescence detection. Anal Biochem. 1995;230(1):24-30. doi:10.1006/abio.1995.1432

76. Hara S, Yamaguchi M, Takemori Y, Nakamura M, Ohkura Y. Highly sensitive determination of $\mathrm{N}$-acetyl- and $\mathrm{N}$-glycolylneuraminic acids in human serum and urine and rat serum by reversed-phase liquid chromatography with fluorescence detection. $J$ Chromatogr B Biomed Sci Appl. 1986;377(C):111-119. doi:10.1016/S03784347(00)80766-5

77. Martín MJ, Vázquez E, Rueda R. Application of a sensitive fluorometric HPLC assay to determine the sialic acid content of infant formulas. Anal Bioanal Chem. 2007;387(8):2943-2949. doi:10.1007/s00216-007-1160-z 
78. Stanton PG, Shen Z, Kecorius EA, Burgon PG, Robertson DM, Hearn MTW. Application of a sensitive HPLC-based fluorometric assay to determine the sialic acid content of human gonadotropin isoforms. J Biochem Biophys Methods. 1995;30(1):3748. doi:10.1016/0165-022X(94)00063-J

79. Spichtig V, Michaud J, Austin S. Determination of sialic acids in milks and milk-based products. Anal Biochem. 2010;405(1):28-40. doi:10.1016/j.ab.2010.06.010

80. Hara S, Yamaguchi M, Takemori Y, Furuhata K, Ogura H, Nakamura M. Determination of mono-O-acetylated $\mathrm{N}$-acetylneuraminic acids in human and rat sera by fluorometric high-performance liquid chromatography. Anal Biochem. 1989;179(1):162-166. doi:10.1016/0003-2697(89)90218-2

81. Kawasaki A, Yasuda M, Mawatari K ichi, et al. Sensitive analysis of sialic acid and related compound by hydrophilic interaction liquid chromatography using fluorescence detection after derivatization with DBD-PZ. Anal Sci. 2018;34(7):841-844. doi:10.2116/analsci.18N001

82. Hara S, Takemori Y, Yamaguchi M, Nakamura M, Ohkura Y. Fluorometric highperformance liquid chromatography of N-acetyl- and N-glycolylneuraminic acids and its application to their microdetermination in human and animal sera, glycoproteins, and glycolipids. Anal Biochem. 1987;164(1):138-145. doi:10.1016/00032697(87)90377-0

83. Zhang Q, Wang Y, Zheng Q, Li J. Analysis of O-Acetylated Sialic Acids in Dried Blood Spots. Anal Chem. 2019;91(4):2744-2751. doi:10.1021/acs.analchem.8b04420

84. Shaw CJ, Chao H, Xiao B. Determination of sialic acids by liquid chromatographymass spectrometry. In: Journal of Chromatography A. Vol 913. ; 2001:365-370. doi:10.1016/S0021-9673(00)01218-8

85. De Leoz MLA, Simón-Manso Y, Woods RJ, Stein SE. Cross-Ring Fragmentation Patterns in the Tandem Mass Spectra of Underivatized Sialylated Oligosaccharides and Their Special Suitability for Spectrum Library Searching. J Am Soc Mass Spectrom. 2019;30(3):426-438. doi:10.1007/s13361-018-2106-8

86. Galuska SP, Geyer H, Bleckmann C, et al. Mass spectrometric fragmentation analysis of oligosialie and polysialic acids. Anal Chem. 2010;82(5):2059-2066. 
doi:10.1021/ac902809q

87. de Haan N, Yang S, Cipollo J, Wuhrer M. Glycomics studies using sialic acid derivatization and mass spectrometry. Nat Rev Chem. 2020;4(5):229-242. doi:10.1038/s41570-020-0174-3

88. Palmisano G, Larsen MR, Packer NH, Thaysen-Andersen M. Structural analysis of glycoprotein sialylation-part II: LC-MS based detection. RSC Adv. 2013;3(45):2270622726. doi:10.1039/c3ra42969e

89. Reiding KR, Bondt A, Hennig R, et al. High-throughput serum N-glycomics: Method comparison and application to study rheumatoid arthritis and pregnancy-associated changes. Mol Cell Proteomics. 2019;18(1):3-15. doi:10.1074/mcp.RA117.000454

90. van der Ham M, Prinsen BHCMT, Huijmans JGM, et al. Quantification of free and total sialic acid excretion by LC-MS/MS. J Chromatogr B Anal Technol Biomed Life Sci. 2007;848(2):251-257. doi:10.1016/j.jchromb.2006.10.066

91. Ho CS, Lam CWK, Chan MHM, et al. Electrospray ionisation mass spectrometry: principles and clinical applications. Clin Biochem Rev. 2003;24(1):3-12.

92. Nishikaze T. Sialic acid derivatization for glycan analysis by mass spectrometry. Proc Japan Acad Ser B Phys Biol Sci. 2019;95(9):523-537. doi:10.2183/pjab.95.036

93. Sekiya S, Wada Y, Tanaka K. Derivatization for stabilizing sialic acids in MALDI-MS. Anal Chem. 2005;77(15):4962-4968. doi:10.1021/ac050287o

94. Harvey DJ. Electrospray mass spectrometry and fragmentation of N-linked carbohydrates derivatized at the reducing terminus. J Am Soc Mass Spectrom. 2000;11(10):900-915. doi:10.1016/S1044-0305(00)00156-2

95. Suzuki Y, Ito T, Suzuki T, et al. Sialic Acid Species as a Determinant of the Host Range of Influenza A Viruses. J Virol. 2000;74(24):11825-11831. doi:10.1128/jvi.74.24.11825-11831.2000

96. Rogers GN, D’Souza BL. Receptor binding properties of human and animal H1 influenza virus isolates. Virology. 1989;173(1):317-322. doi:10.1016/00426822(89)90249-3

97. Wang L, Wang D, Zhou X, Wu L, Sun X-L. Systemic Investigation on Quinoxaline 
Derivatization of Sialic Acids and Their Quantitation Applicability using High Performance Liquid Chromatography. Clin Chem. 1988;34(11):2291-2294.

98. Wylie AD, Zandberg WF. Quantitation of Sialic Acids in Infant Formulas by Liquid Chromatography-Mass Spectrometry: An Assessment of Different Protein Sources and Discovery of New Analogues. J Agric Food Chem. 2018;66(30):8114-8123. doi:10.1021/acs.jafc.8b01042

99. Du J, Zhang Q, Li J, Zheng Q. LC-MS in combination with DMBA derivatization for sialic acid speciation and distribution analysis in fish tissues. Anal Methods. 2020;12(17):2221-2227. doi:10.1039/d0ay00100g

100. X. Lu, I. Yasa, B. Cutak, K. Ray SB. Improving the Chromatographic Separation of DMB-Labeled Sialic Acids for the Comparison of Biosimilars to Reference Materials. Report Appl Newsl. 2015:28-31.

101. DMB-Labeled Sialic Acid Analyses Using HPLC-, UHPLC-, and UPLC-Based, BEH C18 Columns : Waters. https://www.waters.com/nextgen/gb/en/library/applicationnotes/2016/dmb-labeled-sialic-acid-analyses.html. Accessed November 1, 2020.

102. Markely, Lam Raga A, Prajapati S. High-Throughput method for sialic acid quantitation. September 2013.

103. Bhavanandan VP, Sheykhnazari M. Adaptation of the periodate-resorcinol method for determination of sialic acids to a microassay using microtiter plate reader. Anal Biochem. 1993;213(2):438-440. doi:10.1006/abio.1993.1445

104. Abdella N, Akanji AO, Mojiminiyi OA, Al Assoussi A, Moussa M. Relation of serum total sialic acid concentrations with diabetic complications and cardiovascular risk factors in Kuwaiti Type 2 diabetic patients. Diabetes Res Clin Pract. 2000;50(1):65-72. doi:10.1016/s0168-8227(00)00144-3 